6

\title{
A Taxonomic Study of the Ratsnakes, Genus Elaphe Fitzinger. VII. The Triaspis Section.
}

\author{
Herndon G. Dowling \\ Department of Reptiles, New York Zoological Park
}

(Plate I; Text-figures 1-11)

$\mathrm{T}$ HIS paper presents a detailed variational and geographic study of 124 specimens of the ratsnakes of North and Central America formerly known as Elaphe chlorosoma Günther, E. mutabilis Cope and E. triaspis Cope. In the past, these snakes have been confused with one another and with the nightsnake, Elaphe flavirufa Cope.

Their nomenclatural history, however, has not been particularly complex. Smith (1941: 134) recognized the similarities in scutellation and juvenile color pattern between the Central American form E. mutabilis and E. triaspis of the Yucatan Peninsula. On the basis of the similarity in scutellation he suggested that the name Coluber mutabilis Cope, 1885, was based on an albino specimen of E. triaspis Cope, 1866, and belonged in the synonymy of the latter. Stuart (1948: 69) opposed this view, and on the basis of his studies in Guatemala concluded that mutabilis is a valid race of triaspis, ranging from the Petén forest southward to Costa Rica on the Caribbean side of Central America. Further, he predicted that additional material would show that chlorosoma, mutabilis and triaspis are subspecies.

My own studies (Dowling, 1952a: 99-129) showed that although these forms differ in minor ways, they all have the same type of hemipenis, almost identical scutellation and body proportions, and extremely similar juvenile color patterns, and are distinguishable mainly by their adult colors. They also proved to have exclusive ranges, thus corroborating Stuart's suggestion of subspecific relationship. This information was used (Mertens \& Dowling, 1952: 197) in establishing the proper allocation of the name Pityophis intermedius Boettger, 1883. Unfortunately, the type specimen on which this name was based (SMF 34575) belongs to the form previously known as Elaphe chlorosoma Günther, 1894, and it was necessary to place this latter, well-known, name in synonymy. Thus on the basis of these studies the green ratsnake of Arizona and Mexico is Elaphe triaspis intermedia Boettger, the unicolor tan form of the highlands of Central America is E. triaspis mutabilis Cope and the blotched form of the Yucatan Peninsula is E. t. triaspis Cope (Dowling, 1952b: 7-8).

The characteristics of hemipenis, body proportions, scutellation and juvenile color pattern that indicate the close relationship of the three forms treated here also separate them from all other American species of Elaphe. None of the other American species shows any approach to $E$. triaspis in these ways and it for this reason that it is recognized as a separate section of the genus. These American sections of the genus Elaphe have been mentioned before, but only the Rosaliae section (Dowling, 1957: 1), has been previously defined. The Triaspis section is defined below, and the three sections recognized among American members of the genus may be distinguished by the following key.

1. Proximal half of hemipenis covered with spinules ............ Rosaliae section

1'. Proximal half of hemipenis smooth or folded, but without spinules ..............

2. A pair of elongate fleshy spines (basal hooks) at the proximal edge of the spinose portion of the hemipenis; a single distal lobe......... .............. Triaspis section (p. 54)

2'. No basal hooks; two distal lobes. . . . . . . . . . ................ Pantherophis section

While only hemipenial characters are used in the key, actually the sections also differ in characters of coloration, body proportions, scutella- 


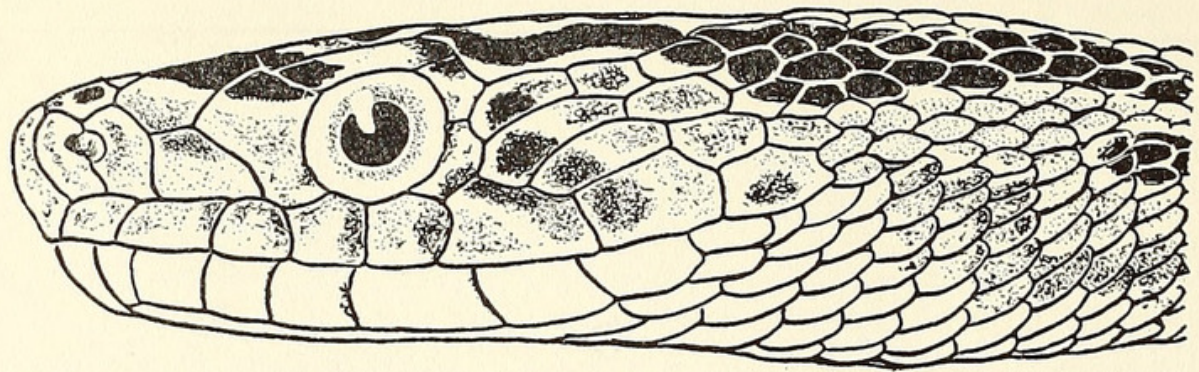

TEXT-FIG. 1. Lateral view of the head of a juvenile specimen of $E$. $t$. triaspis. The three elongate primary temporals are characteristic of this species. Since only two of the temporals are in contact with the postoculars, such a condition would be recorded as $2(3)+3+4$.

tion and skeleton. Many genera of colubrid snakes have been erected on lesser grounds, but none is proposed here because of the possibility that the relationships of these groups may be demonstrated, at some later date, to lie with other Old World genera (vide infra, "Relationships").

Definition of the Triaspis Section.-Snakes of the genus Elaphe that possess a large hemipenis which extends at least to caudal 15 and often to caudal 19 in the inverted position, with two large basal hooks, and without spinules proximally or lobes distally (Plate I). There are usually three elongate primary temporals, no lorilabial scales, and eight to ten supralabials (Text-fig. 1). The ventrals range from 241 (male) to 282 (female) with a dimorphism of more than 15 ventrals in favor of the females; the caudals range from 87 (female) to 126 (male) with the males having about 13 more than the females.

Since a single American species is contained in this section, further discussion will be carried on under the specific name.

\section{Elaphe triaspis Cope}

Coluber triaspis Cope, 1866: 128; type locality, "Belize."

This species ranges from the mountains of southeastern Arizona along the edge of the Mexican plateau, southward in the highlands of Central America to Costa Rica. It is also found on the eastern rim of the plateau and in the lowlands of the Yucatan peninsula (Text-fig. 2).

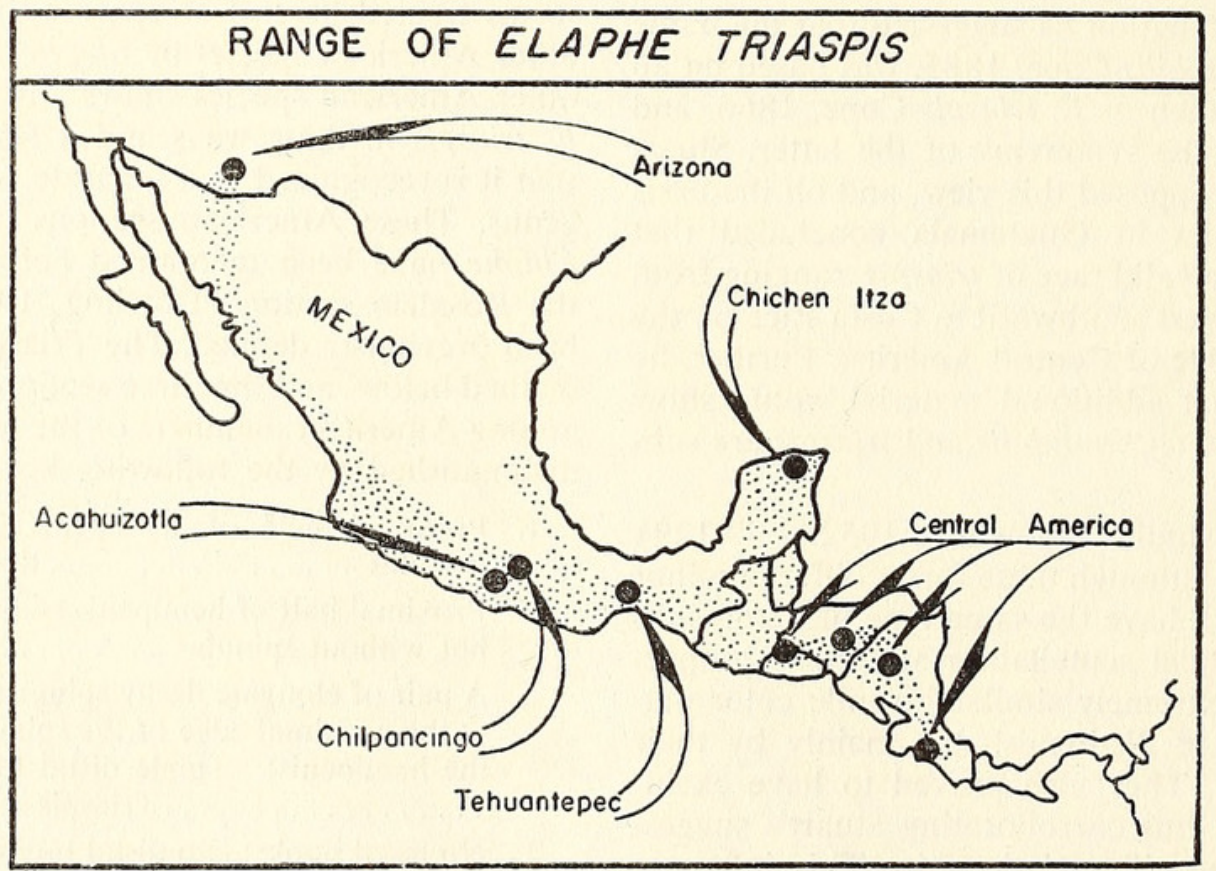

Text-Fig. 2. Map of Middle America showing geographic distribution of Elaphe triaspis and the localities from which series of these snakes are available. As indicated, it was necessary to group the specimens from several localities to obtain a usable series from Central America. 


\section{General MoRPHOLOGY}

Elaphe triaspis varies in adult color pattern, scutellation and body proportions in the different parts of its range. The variation in scutellation appears to be non-clinal for the most part, so that little prediction can be made concerning the snakes of a particular area on the basis of the characteristics of specimens from adjacent regions.

The general habitus of this species is a long sub-cylindrical body, a narrow head, a rather pointed snout and a long tapering tail. The ventrals are distinctly angulated laterally but are notched only in large adults, a condition probably resulting from wear. The eye is small $(\mathbf{M}=c a .13 .5$ per cent. of head length in adults), and this together with the somewhat compressed body, the numerous dorsal scales and the narrow head gives these snakes a boid appearance. Although narrow, the head is rather long and makes up 3 to 4 per cent. of the body length in adults and an even greater proportion in the young. The tail is longer than in any other American species of the genus, ranging from 23 to 26 per cent. of the body length in adult females, and up to 30 and 35 per cent. in adult males.

Judging from the specimens examined, these snakes are of medium size. However, they may attain lengths greater than those shown in the relatively small number of adult specimens available. The largest specimens examined were somewhat less than $1,300 \mathrm{~mm}$. in total length.

Skeleton and Teeth. - Hypapophyses are found only on the anterior vertebrae in this species, as in other members of the genus. It was noted in one specimen from Yucatán $(\mathrm{MCZ}$ 28751) that had been slit longitudinally that the hypapophyses disappear at the level of the fiftysecond ventral scute. In five specimens from Guerrero that had been similarly slit (TCWM $7430-32,8579,12651)$ the hypapophyses disappear at the levels of the forty-seventh to the fifty-fourth ventrals, without any visible sexual differences.

A single skull of this species is available: an adult specimen from near Tehuantepec, Oaxaca (UMMZ S-1082). It differs from the skulls of other American members of the genus Elaphe mainly in that the anterolateral edges of the nasals are extended forward and outward, giving these bones a quadrangular appearance in contrast to the rounded shape in other species. Other bones of the skull also show minor, but distinctive, differences (Dowling, 1958: Fig. 2 ). The tooth counts of this specimen are: maxillary 21-21, palatine 12-11, pterygoid 19-18, dentary $26-26$. The teeth decrease slightly in length toward the posterior end of all the bones. The close correspondence of the tooth counts of this specimen with that of E. subocularis (Dowling, 1957: 2) points up the futility of using quantitative characters in determining the phylogeny of this group of snakes.

Hemipenis.-As indicated in the definition of the Triaspis section, the hemipenis is distinctive in this species and many of its features are found in no other American form of the genus. Though strict measurement of an extensile organ is not possible, it is evident that the hemipenis of E. triaspis is considerably larger than that of other ratsnakes of comparable size. When observed in the inverted position by dissection, its posterior end is found to lie between caudals 15 and 19.

Unfortunately, no completely everted hemipenis of this species is available for figuring or description. The inverted hemipenis of an adult male (body length $=726 \mathrm{~mm}$.) from the city of Colima, Colima (UMMZ 80210), was split longitudinally and spread flat to be used for the description that follows.

The hemipenis (Plate I, Fig. 1) extends to caudal 15. It is single, not bilobed, and the sulcus is simple. The proximal one-fifth of the organ has neither spines nor calyces; it is folded and somewhat rugose, but this is probably the result of preservation. At the distal end of the naked area is a pair of large straight fleshy spines (basal hooks), one on either side of the sulcus. Distal to these are three or four rows of similar but smaller spines that decrease abruptly in length distally and disappear on the proximal half of the organ. The spines are replaced by 21 or 22 oblique rows of papillate calyces that decrease in size distally, but which apparently continue to the end of the organ. The calyces are lozenge-shaped and each of the four sides has from three to five stiff papillae. The lips of the sulcus are not conspicuously raised and have no special ornamentation.

The hemipenis of another specimen from Arizona (W. H. Woodin, No. 560) has the following proportions: the organ extends to caudal 16 , it is unornamented proximally, the basal hooks arise at caudal 6 and extend to caudal 3, the spinose portion begins with the basal hooks at caudal 6 and extends to caudal 9 and the entire portion distal to caudal 9 is calyculate. These proportions are very similar to those of the figured specimen from Colima.

Scutellation.-E. triaspis has large numbers of ventrals, caudals and dorsals, but has no peculiar features of scutellation (such as the lorilabials of the Rosaliae section) to distinguish it from certain members of the Pantherophis sec- 
tion. One characteristic of E. triaspis that is seldom found in other species is the presence of three elongate primary temporals (Text-fig. 1). These scutes slant downward anteriorly and often (as in the figure) one of them is excluded from contact with the postoculars, giving a strict primary temporal count of two, though the third temporal is present farther back. In this paper such a condition is indicated as $2(3)+3+4$ for the temporals of one side, or $4(6)+6+8$ when those of both sides are added.

Coloration.-E. triaspis agrees with other American ratsnakes in having a juvenile pattern of blotches, which may or may not be retained in the adult. It also has a trace of the postorbital bar that is characteristic of the genus in this hemisphere (Text-fig. 1). It differs, however, in possessing a unique head pattern (Text-fig. 9). Another differential feature of coloration is that of the individual dorsal scales. Although not shown well in all preserved specimens, the base of each scale is black, and there is a white streak along one or both proximal edges. This feature is particularly evident in the snakes from Colima and in those from the Yucatan Peninsula.

\section{Natural History}

Little is known of the habitat preference of $E$. triaspis because, as is the case with most large snakes (with the possible exception of watersnakes), most of the specimens were collected on roads and trails. From the elongate habitus, angulate ventrals and rather small eyes, it might be postulated that this snake is arboreal and diurnal. The long tail and green coloration of the northern form are especially indicative of a treesnake, but it is not known whether or not this form differs from the others in this respect.

The Central American snakes appear to be found only in mountain regions of moderate ( 300 to 1,500 meters) elevation. The vegetation at this altitude is usually montane mesophytic forest. The snakes of eastern Mexico are also found in this habitat. However, in western and southern Mexico they may be found either in the mesophytic forest (Acahuizotla) or in xeric conditions that approach thorn scrub (Colima and Balsas Valley). Thus, a broad range of habitats has been recorded. The blotched form is found over most of the Yucatan Peninsula at altitudes of less than 300 meters. The vegetation in this region, also, is the thorn forest typical of areas of high evaporation rate and relatively low rainfall.

Several of the specimens examined had been opened to remove some food animal, but none appears to have been saved or recorded. One specimen from the vicinity of Chilpancingo,
Guerrero (MVZ 45085), had a few mammal hairs in its stomach, and a specimen recorded by Duellman (1958: 11) from Colima had a Mus musculus in its stomach.

The information on breeding habits is also meager. A specimen from Chichen Itza, Yucatán (AMNH-38843), contains two large eggs. It was collected on October 17, 1929.

\section{RELATIONSHIPS}

As previously indicated, E. triaspis shows no close relationship with any other American species of Elaphe, differing in the distinctive hemipenis, the shape of bones of the skull, the color pattern and in the degree of sexual dimorphism. It is particularly interesting, therefore, that recent examination of the hemipenis of a European species, Elaphe longissima Laurenti, reveals resemblance to that of E. triaspis. $E$. longissima, however, differs radically from triaspis in body proportions and scale counts. Some method of assaying the relative value of these (various) features must be established to test the validity of this suggested relationship. Closer relations would be expected between American snakes and those of eastern Asia than between American and European ones. However, it may be emphasized that this is the only Old World species of Elaphe that has been found to have additional resemblances to the American forms other than those of habitus and scutellation.

\section{VARIATION}

Sexual dimorphism, ontogentic change and individual variation within and between the several populations are here treated separately. However, the samples of $E$. triaspis from many of the localities are too small to assay the amount of variation within the unit populations represented. Therefore, it sometimes becomes necessary to combine the data obtained from the various small series from different part of the geographic range and to use the aggregate for analysis and comparison.

\section{SERIES Used IN THE STUdY}

Moderately adequate series of specimens from single, specific localities, and inadequate ones from two or more sources (which by necessity are grouped) are described briefly here. They are referred to by name in other sections of this paper (Text-fig. 2).

Arizona Series.-The seven snakes from this state (five males and two females) are grouped here as representative of the populations inhabiting this northernmost part of the range. Three different localities are represented. 
Chichen Itza Series.-This is the largest series available. Collected by various persons who visited the famous Mayan ruins of that name on the Yucatan Peninsula, it is made up of ten males and twelve females.

Chilpancingo Series.-A series of seven males and nine females has been collected over a period of years (1936-1946) by W. Wilmot Brown from the vicinity of Chilpancingo, Guerrero. This may actually embrace a large area as some of the specimens were undoubtedly bought from wandering hunters. However, their characters demonstrate that they were not taken from the Pacific slope of the Sierra Madre del Sur.

Acahuizotla Series.-Six males and two females were collected from about 1 mile west of the village of Acahuizotla, Guerrero, by W. B. Davis and his field party in the summer of 1952.

Tehuantepec Series.-Eight males and five females have been collected from the mountains northward and eastward of the town of Tehuantepec, Oaxaca, by various field parties. They come from several localities, and would not have been grouped as a series except that the males form a closely-knit morphological unit, with less variation than is shown by some series from precise localities.

Central American Series.-No true series is available from the southernmost part of the range. Although some geographic variation probably is demonstrated here (e.g., in dorsal scale row number), the eight snakes from Honduras, Nicaragua, and Costa Rica, (and certain data on two snakes from El Salvador) are here grouped as representative of this region.

\section{Sexual Dimorphism}

Only three of the above series have a sufficient number of specimens of both sexes to give meaningful information by statistical treatment. These are the series from Chichen Itza, from Chilpancingo and from Tehuantepec. The information on sexual dimorphism derived from these few snakes is corroborated by that obtained from study of the other series and scat- tered specimens and is not contradicted in any way. Thus the data obtained from these three series are taken to be representative of the species as a whole.

In the series used here the number of snakes is too small to determine whether or not there is dimorphism in characters that have narrow ranges of variation such as in labials, temporals or maxillary teeth. Even the more variable characters may be assayed only roughly. However, as in many species of snakes, the males of $E$. triaspis have distinctly shorter bodies and longer tails than the females do. These differences are notable in the linear measurements, in the number of blotches on the tail and are especially evident in the numbers of ventral and subcaudal scutes. No other American species of the genus Elaphe approaches E. triaspis in the development of sexual dimorphism in these two latter characters.

Ventrals.-The Chichen Itza series shows a mean difference of 15.4 ventrals between males and females, and this is the least sexual dimorphism reflected by this character anywhere in the range of this species. The other two series show an average sexual difference of about 20 ventrals (Table I). While larger series from any locality might show overlap in ventral numbers between male and female snakes, the Chichen Itza series is the only one that does so (by a single ventral). All of the other specimens are identifiable as to sex on the basis of ventral number alone, and the greater dimorphism outside the Yucatan Peninsula region makes it probable that no overlap will be found outside that area.

This sexual divergence may be compared with the situation in other American species of Elaphe, where the mean difference between sexes is usually less than 10 ventrals with considerable overlap (vide Conant, 1938: 56, for E. obsoleta Say and 1940: 9, for E. vulpina Baird \& Girard). In the Rosaliae section, the only species with ventral scutes in about the same numbers as in E. triaspis, no sexual dimorphism is observable (Dowling, 1957: 4). The unusual amount of sexual divergence in

Table I. Sexual Dimorphism in Number of Ventrals

\begin{tabular}{|c|c|c|c|c|c|c|c|c|c|}
\hline \multirow[b]{2}{*}{ Series } & \multicolumn{3}{|c|}{ Males } & \multicolumn{3}{|c|}{ Differences } & \multicolumn{3}{|c|}{ Females } \\
\hline & $\mathrm{N}$ & M & $\mathrm{SE}$ & DM & CD & CSD & $\mathrm{N}$ & $\mathbf{M}$ & SE \\
\hline $\begin{array}{l}\text { Chichen Itza } \\
\text { Chilpancingo } \\
\text { Tehuantepec }\end{array}$ & $\begin{array}{r}10 \\
7 \\
8\end{array}$ & $\begin{array}{l}253.40 \\
244.43 \\
254.13\end{array}$ & $\begin{array}{l}1.46 \\
0.81 \\
0.97\end{array}$ & $\begin{array}{l}15.4 \\
20.5 \\
20.3\end{array}$ & $\begin{array}{l}1.86 \\
1.97 \\
2.67\end{array}$ & $\begin{array}{l}5.91 \\
8.05 \\
7.67\end{array}$ & $\begin{array}{r}12 \\
9 \\
5\end{array}$ & $\begin{array}{l}268.83 \\
264.89 \\
274.40\end{array}$ & $\begin{array}{l}1.07 \\
1.62 \\
3.00\end{array}$ \\
\hline
\end{tabular}

$\mathbf{C D}=$ coefficient of divergence; $\mathbf{C S D}=$ coefficient of sexual dimorphism; $\mathbf{D M}=$ difference between means; $\mathbf{M}=$ mean; $\mathbf{N}=$ number of specimens; $\mathbf{S E}=$ standard error of mean. 
Table II. Sexual Dimorphism in Number of Subcaudals

\begin{tabular}{|c|c|c|c|c|c|c|c|c|c|}
\hline \multirow[b]{2}{*}{ Series } & \multicolumn{3}{|c|}{ Males } & \multicolumn{3}{|c|}{ Differences } & \multicolumn{3}{|c|}{ Females } \\
\hline & $\mathrm{N}$ & M & $\mathrm{SE}$ & DM & $\mathrm{CD}$ & CSD & $\mathrm{N}$ & $\mathrm{M}$ & $\mathrm{SE}$ \\
\hline Chichen Itza & 10 & 106.80 & 1.41 & 13.20 & 1.82 & 13.16 & 9 & 93.56 & 1.11 \\
\hline Chilpancingo & 5 & 109.00 & 1.14 & 17.71 & 1.25 & 17.68 & 7 & 91.29 & 0.68 \\
\hline Tehuantepec & 6 & 122.83 & 1.13 & 22.23 & 1.64 & 19.90 & 5 & 100.60 & 1.18 \\
\hline
\end{tabular}

$\mathbf{C D}=$ coefficient of divergence; $\mathbf{C S D}=$ coefficient of sexual dimorphism; $\mathbf{D M}=$ difference between means; $\mathbf{M}=$ mean; $\mathbf{N}=$ number of specimens; $\mathbf{S E}=$ standard error of mean.

E. triaspis has not been recognized previously and it has caused some workers, (e.g., Hall, 1951: 204) to suspect that their series were composites, with more than one species represented. The situation has been obscured because many authors disregard the sex of their specimens.

Subcaudals.-Sexual dimorphism in subcaudal numbers is not an unusual feature in snakes, but it is usually more pronounced in short-tailed species. However, it is present in the long-tailed $E$. triaspis to about the same degree (if the actual number of scutes is considered) or to a greater extent (if the coefficient of sexual dimorphism is used) as in the ventrals (Table II).

Dorsals.-The dorsal scales range from minima of 23 anteriorly, 29 at midbody and 18 posteriorly, in almost every combination to maxima of 33, 39 and 25. A greater posterior count in females has been described for many species (e.g., Blanchard, 1921: 12, in Lampropeltis). In $E$. triaspis the females exceed the males in the anterior and midbody counts as well. This is shown by both the extremes and the means in all three of the series considered here (Text-fig. 3).

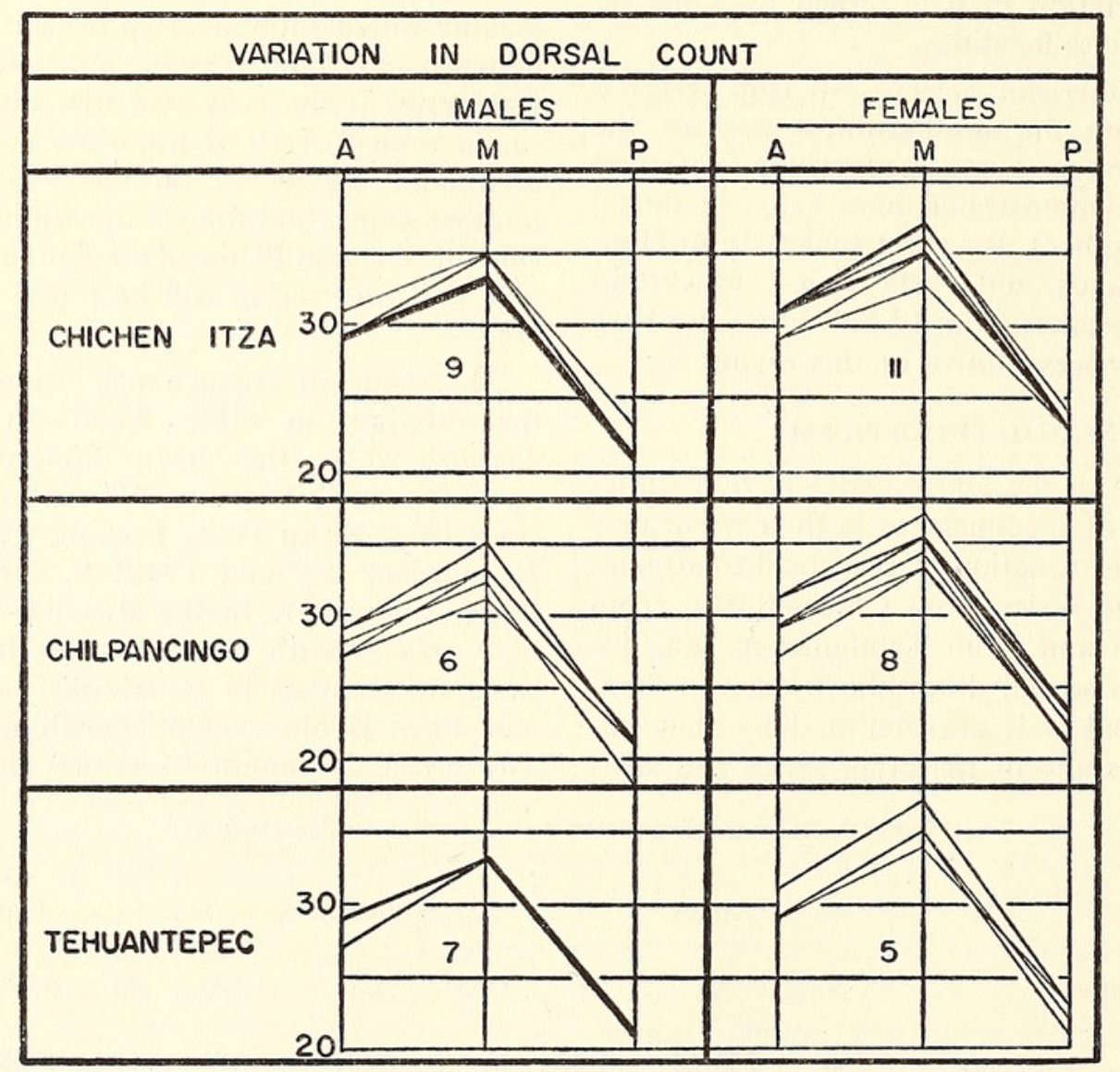

Text-FIG. 3. Variation in dorsal scale count in Elaphe triaspis. The females exceed the males at every body region. ( $A=$ anterior count, $M=$ midbody count, $P=$ posterior count; the numbers under the figures indicate the number of specimens in each series). 
Body Length and Proportions.-The same features that are revealed in the ventral and subcaudal scute counts are also notable in body and tail lengths. The females exceed the males only slightly in total length, but their body lengths are much greater. Proportional length calculations are complicated by the incomplete tails and twisted bodies of many of the specimens, and also by ontogenetic and geographic variations. Nevertheless, the sexual dimorphism is great enough to be seen in the few specimens for which accurate measurement is possible.

The largest male specimen available (AMNH 65891 , from Oaxaca) has a body length of 902 $\mathrm{mm}$. and a tail length of 311. Comparable measurements of the largest female specimen (UMMZ 99893, from Puebla) are about 980 and 242. The largest male is the only one with a body length greater than $900 \mathrm{~mm}$.; most males range between 600 and $800 \mathrm{~mm}$. This is not true of the females: 15 of them exceed $900 \mathrm{~mm}$. in body length.

The Chichen Itza series has 16 measurable specimens (nine males and seven females). The males have a mean proportional tail length of 26.6 per cent. and an observed range of 24.7 to 29.5. The females have a mean of 22.4 per cent. and an observed range of 21.1 to 23.9 .
The Chilpancingo series has nine measurable specimens (four males and five females). The males show an average proportionate tail length of 30.3 per cent., with a range of 26.3 to 32.2 . The females have a mean of 21.6 per cent. and a range of 18.9 to 23.4 .

The Tehuantepec series has only six measurable specimens (four males and two females). The males have a mean proportional tail length of 32.9 per cent., with a range of 29.9 to 35.4 . The two females have proportional tail lengths of 21.9 and 25.2 , giving a mean of 23.5 per cent.

According to these figures the Chichen Itza series demonstrates less sexual dimorphism in tail length than do the other two series. (This was also noted in ventral and caudal scute numbers.) A plot of tail length against body length (Text-fig. 4) corroborates these data and shows that the females of all three series have approximately the same body proportions but that the difference between the sexes in the Chichen Itza series is less than in the other two.

Blotch Numbers.-Only in the Chichen Itza series are there enough blotched specimens to test for sexual dimorphism. None of significance is revealed by the number of body blotches ( $M=49.1$ in males, 48.8 in females) but the number of tail blotches does differ sexually. The

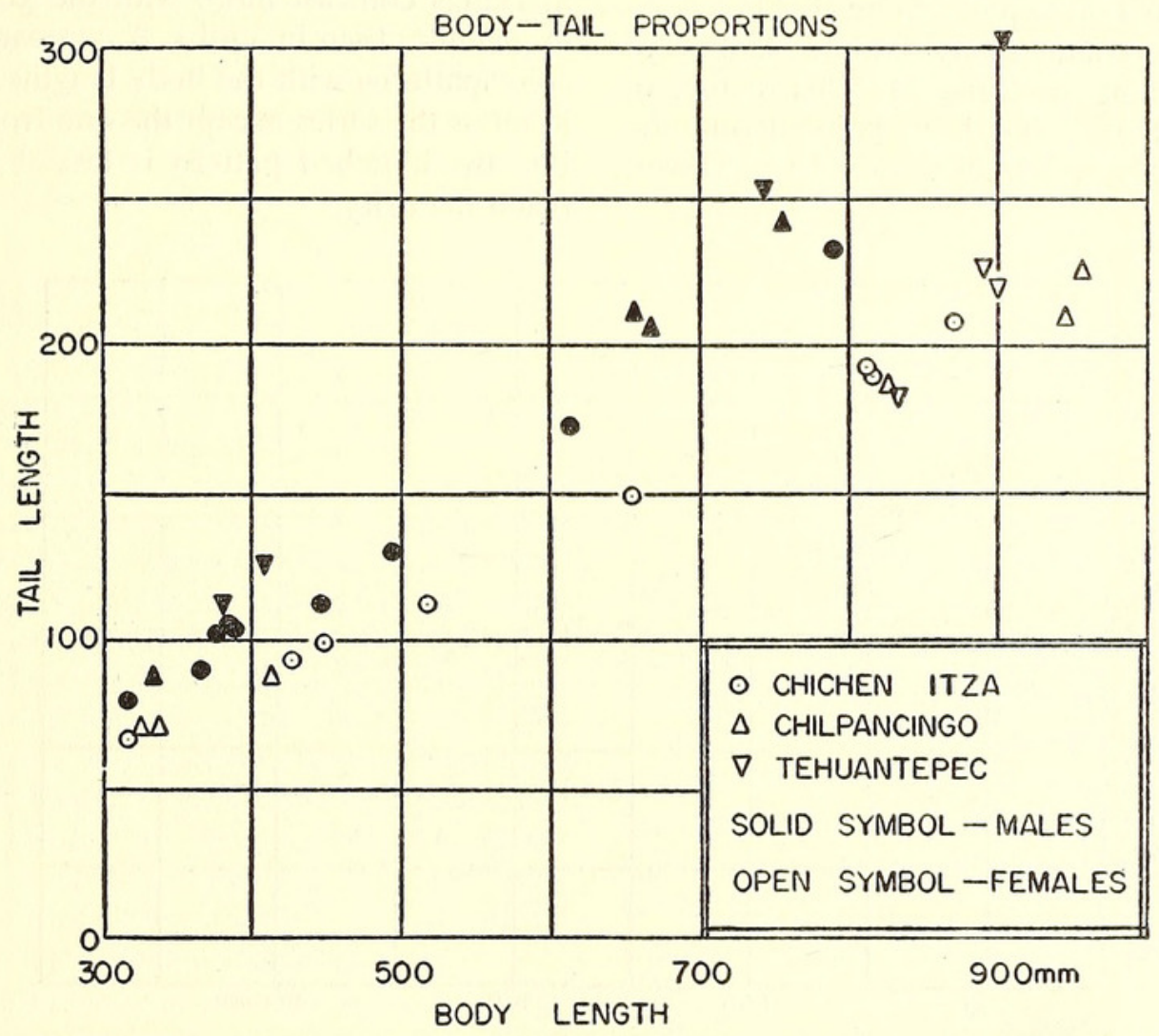

TEXT-FIG. 4. Comparison of body proportions in three populations of Elaphe triaspis. While no differences are apparent in the female snakes, the males from Chichen Itza have shorter tails than do those of the other two populations. Note also the considerable sexual dimorphism in this feature. 
males range from 23 to 31 tail blotches $(M=26.1 \pm 0.75)$ and the females from 17 to $22(\mathrm{M}=19.8 \pm 0.55)$.

\section{ONTOGENETIC VARIATION}

The changes in body proportions that are usual in the growth of snakes from juveniles to adults may be seen to some degree in the small series available here. A feature not so commonly found in snakes is the presence of a striking ontogenetic change in the color pattern in some series, and its absence in others.

Body Proportions. - Measurements were taken of body length, tail length, head length and eye diameter in all specimens where it was possible to do so. Ratios derived from these measurements that are used here are the proportional head length, proportional eye length and proportional tail length.

A plot of proportional head length against body length for the three larger series reveals that there is little or no difference between the sexes in this feature. The juvenile snakes, those with body lengths of less than $500 \mathrm{~mm}$., however, have much larger heads, proportionately, than the adults do. While there is some continuation of the proportional reduction in head size in snakes with body lengths of more than 500 $\mathrm{mm}$., the reduction appears to be slight as compared with the changes between body lengths of 300 to $500 \mathrm{~mm}$. (Text-fig. 5). This feature of ontogenetic change has been pointed out previously in other genera of snakes (e.g., Oliver, 1948: 191).
A plot of the eye diameter against the head length demonstrates that the small juveniles tend to have larger eyes, proportionately, than the adults and subadults. The proportion is so variable, however, (probably due to the difficulty of obtaining an accurate measurement of the eye), that any possible sexual or geographic differences are obscured.

As indicated in the section on sexual dimorphism, the proportional tail lengths demonstrate sexual, geographic and ontogenetic differences (Text-fig. 4). The juvenile snakes have shorter tails than the adult members of their sex: those of juvenile females range upward from 19 per cent. of body length, and those of juvenile males range upward from 25 per cent., as compared with proportions of 23 to 26 per cent. in adult females and 28 to 35 per cent. in adult males. This situation is in contrast to that in the Rosaliae section of the genus (Dowling, 1957: 2) where the juvenile snakes were found to have tails proportionately longer than those of the adults. Thus in this character E. triaspis agrees with such genera as Diadophis, Phyllorhynchus and Tantilla, while the Rosaliae section agrees with Pituophis, Lampropeltis and other snakes (Klauber, 1943: Table 6).

Color Pattern.-In all of the snakes the dark markings contrast more with the ground color in juveniles than in adults. A comparison of the color patterns with the body lengths shows that in all of the series except the one from Chichen Itza the blotched pattern is lost as the snakes reach maturity.

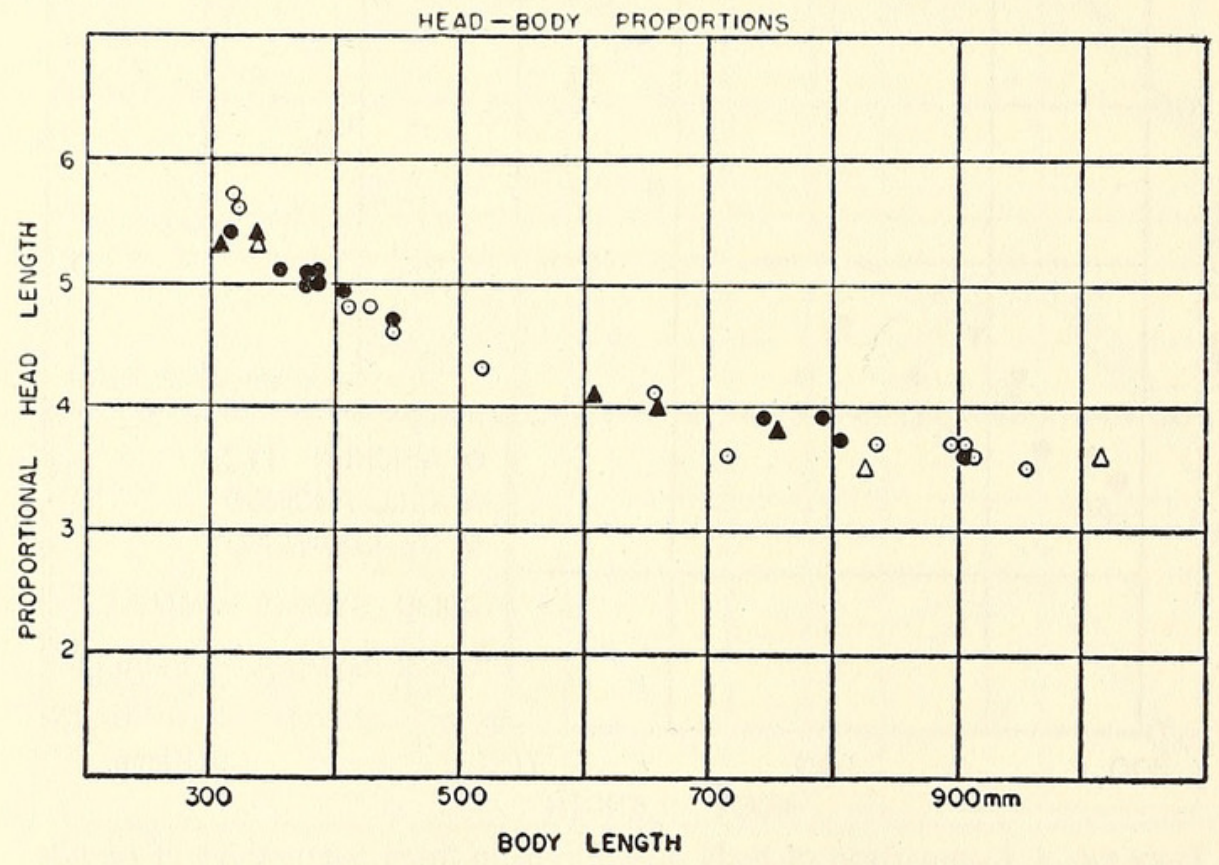

Texr-FIG. 5. Ontogenetic variation in head and body lengths in Elaphe triaspis. Note the differential growth in juvenile snakes (less than $600 \mathrm{~mm}$. in body length) as compared with the adults. 
The snakes remain blotched throughout their lives (at least to body lengths of over $900 \mathrm{~mm}$.) at Chichen Itza. The only differences visible in the preserved specimens at hand are due to the lessening of contrast between blotches and ground color. The ground color, which is light brown in preservative, does not appear to change ontogenetically but the dark markings become less intense. Both body and tail blotches remain sufficiently distinct to be counted easily even in the largest specimens, however. The ventral color is immaculate cream below the angle of the ventral scutes. This color becomes progressively mottled with gray from the posterior end forward as the individuals increase in length, but in none does the gray become dominant.

In all of the other series there is an abrupt change in the dorsal coloration at a body length of about $600 \mathrm{~mm}$. In the Central American series two specimens (MCZ 49804 and 49895 with body lengths of 564 and 638 respectively) appear to show the transition of blotched to unicolor. The body blotches of the former are diffuse but sufficiently distinct to be counted. The tail blotches have disappeared. In the latter specimens the blotches are faintly indicated on the anterior half of the body but are too diffused to be counted on the posterior part or on the tail. The specimens with body lengths below $500 \mathrm{~mm}$. in this series are distinctly blotched; a specimen with a body length of $795 \mathrm{~mm}$. has no trace of blotches, although the head pattern is faintly visible.

Neither the Chilpancingo nor the Tehuantepec series contains specimens of proper size to determine the length at which the change occurs. The small snakes (less than $420 \mathrm{~mm}$. in body length) are light brown with distinct dark blotches, the large ones (more than $600 \mathrm{~mm}$.) are unicolor gray, gray-brown or greenish. The Arizona series, however, does have snakes of the proper size. A specimen (UIMNH 29182) with a body length of $628 \mathrm{~mm}$. has faint, but countable, blotches on the body but not on the tail. Another specimen (DZUA 500) with a body length of about $650 \mathrm{~mm}$. is unicolor gray. P. W. Smith (in litt.) informed me that the specimen with a body length of $628 \mathrm{~mm}$. showed no pattern at all in life, but was uniform gray-green. One specimen from the Tehuantepec series with a body length of 894 (UMMZ 82570) still has the head pattern faintly indicated.

Thus in all the series other than the one from Chichen Itza the dorsal pattern changes from $\tan$ with dark blotches to unicolor tan or green at a body length of about $600 \mathrm{~mm}$. The tail blotches fade first, then those on the posterior part of the body, and the head pattern remains until last (Text-fig. 6).

Keeling of Dorsal Scales.-The dorsal scales may be either smooth or faintly keeled at midbody, but some are always keeled on the posterior part of the body. This character is difficult to use in a precise fashion in these snakes since the condition of the specimen influences the amount of keeling apparent: soft specimens that have lost the epidermis will not show keeling that might have been present, while specimens preserved in strong formalin solutions may have wrinkled dorsal scales that give a false impression of keeling. Nevertheless, it may be seen that the series available differ in the amount of keeling present.

A plot of the number of keeled rows at midbody against the body lengths of the snakes has been prepared for four of the series (Text-fig. $6)$. The increase in dorsal keeling in larger individuals may be seen in all. It seems possible that the poor condition of the specimens was responsible for the lack of apparent keeling at midbody in the five individuals of the Chichen Itza series.

A single adult individual (of five) in the Arizona series has five dorsal rows keeled at midbody; two adults (of 10 ) have three rows keeled and one has five in the Chilpancingo series; one adult (of five) has three dorsal rows keeled in the Tehuantepec series. None of the juvenile snakes of any of these series shows any trace of keeled scales at midbody, though all have at least seven dorsal rows keeled above the cloacal opening.

The two series that demonstrate moderately heavy dorsal keeling, therefore, show the progressive ontogenetic increase in keeling that has already been shown to occur in $E$. guttata, $E$. obsoleta (Dowling, 1951: 41) and E. subocularis (Dowling, 1957: 13).

\section{INDIVIDUAL VARIATION}

The individual variation in morphological characters that also varies sexually or ontogenetically has been described above. These characters include number of ventrals, subcaudals, dorsals, keeled scales and tail blotches, and various proportional measurements. The remaining characters that were not previously described include number of oculars, temporals, labials, gulars, maxillary teeth and body blotches (Table III).

Oculars.-There are usually one preocular and two postoculars on each side of the head. Other than a single specimen from the Chilpancingo series with two preoculars on one side (and the 


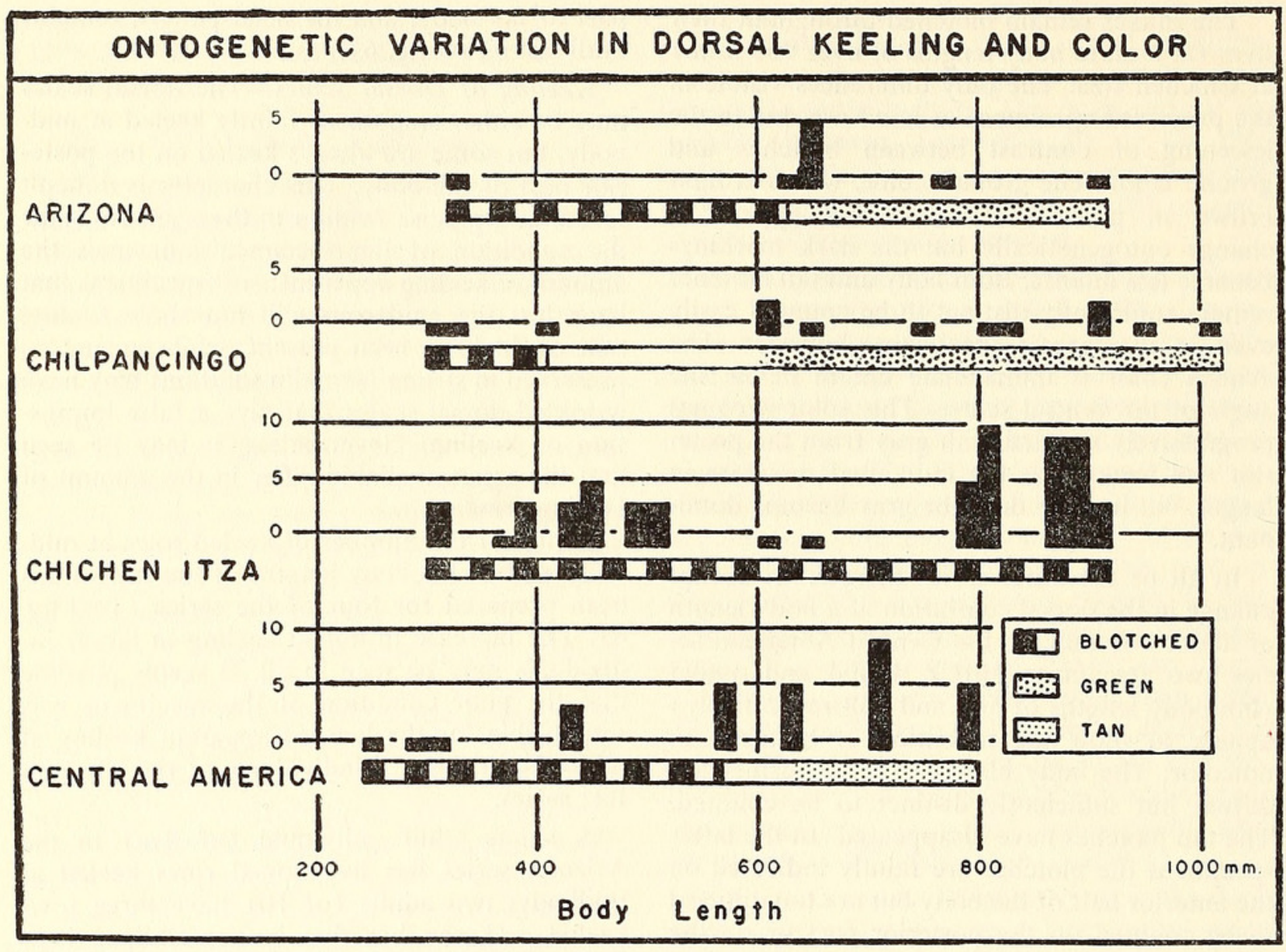

TEXT-FIG. 6. Ontogenetic variation in dorsal keeling and color in four populations of Elaphe triaspis. The juvenile snakes (less than $600 \mathrm{~mm}$. in body length) are smooth-scaled in the Arizona and Chilpancingo series but the Chichen Itza and Central American snakes show some midbody keeling at a body length of $400 \mathrm{~mm}$. The adults of the two latter series tend to have at least five rows keeled at midbody, while those of the former series are usually smooth. The change in coloration at a body length of about $600 \mathrm{~mm}$. is shown by all series except that from Chichen Itza.

one on the other partly divided), the only variation is found in the Chichen Itza series. Here, also, one specimen has two preoculars on one side, and nine specimens have three postoculars on one or both sides.

Temporals.-The numerous and irregular temporals in these snakes are difficult to count and the recorded numbers may not be completely accurate. As indicated, however, there are usually three temporals in the primary row, although occasionally only two (and rarely only one) are in contact with the postoculars. The secondary row usually has three or four scales, and sometimes five, and the tertiary row has from four to six scales, most commonly five. The numbers in each row and on each side of the head seem to bear little relation to one another, making the actual counts highly variable.

Supralabials.-The usual supralabial count is eight, as in most of the American snakes of this genus. Nine supralabials are occasionally found in all of the series, and are common in the one from Chichen Itza which also has four individuals with ten supralabials on one or both sides.

Infralabials.-The infralabials vary from 10 to 12 on a side, with the usual number being 11 in all series.

Gulars.-The gulars range from three to five; most individuals have four.

Maxillary Teeth.-The maxillary teeth range from 19 to 24 ; most individuals have either 21 or 22.

Body Blotches.-The body blotches range from 43 to 73 . However, this is a geographically variable character and none of the series shows a variation of more than 15 blotches.

\section{GeOgRAPHIC VARIATION}

Some geographic variation is to be expected in a species of snake that ranges from Costa Rica to Arizona, a distance of more than 2,500 miles. The usual method of presenting data on geographic variation is to distinguish the sub- 
species, and then describe each as a unit. This type of presentation presupposes a certain amount of grouping by the worker that is not obvious to the reader. Such grouping may be warranted for many species but for E. triaspis it seems to be unwarranted for the treatment of the more variable characters such as ventrals, subcaudals or body blotches, and may be so for the others. Thus instead of the preliminary grouping here, a method of presentation that more nearly approximates the actual procedure of evaluation is adopted. First, the various series of snakes that have been used are described concisely, then the similar series are grouped, together with what individual specimens appear to belong with them on the bases of geographic probability and morphological characters. The proper names for any distinguishable population groupings are then determined by reference to type specimens and original descriptions.

The series are described in north-to-south order. The Chichen Itza series is, of course, offset from any linear arrangement. The descriptions are comparable only to one another, and it should be remembered throughout that Elaphe triaspis is a slender, long-tailed and weaklykeeled snake in relation to other species of the genus.

Arizona Series.-A population of relatively long-tailed snakes with weakly keeled dorsals and large numbers of ventrals and caudals (Table IV). The blotched color pattern of juvenile snakes is lost in the adults, which are uniform gray-green. Philip W. Smith wrote (in litt.) concerning one of these (UIMNH 29182) : "In life it was a very pretty gray-green, not the green of Opheodrys aestivus but almost the same shade as Illinois $O$. vernalis. No pattern at all was evident. The dorsal blotches [which are faint, but countable in the preserved specimen] have appeared since ... [ [preservation]." The two young that still show blotches have 69 and

Table III. Individual Variation in Selected Characters in Elaphe triaspis

\begin{tabular}{|c|c|c|c|c|c|c|}
\hline Character & Arizona & Chichen Itza & Chilpancingo & Acahuizotla & Tehuantepec & $\begin{array}{l}\text { Central } \\
\text { America }\end{array}$ \\
\hline Oculars & $2+4[7] 1$ & $\begin{array}{l}2+4[11] \\
2+5[6] \\
2+6[3] \\
3+5\end{array}$ & $\begin{array}{l}2+4[13] \\
3+4\end{array}$ & $2+4[8]$ & $2+4[12]$ & $\begin{array}{l}2+2 \\
2+4[7]\end{array}$ \\
\hline Temporals & $\begin{array}{c}3(6)+8+9 \\
4(5)+7+8 \\
4(6)+6+9 \\
4(6)+7+9 \\
4(6)+7+10 \\
4(6)+8+9 \\
6+6+8\end{array}$ & $\begin{array}{l}3(6)+8+10 \\
4(6)+6+9 \\
4(6)+6+10 \\
4(6)+7+10 \\
5(6)+6+10 \\
6+6+8[3] \\
6+6+9 \\
6+6+10 \\
6+7+9 \\
6+7+10[3] \\
6+7+11 \\
6+7+12 \\
6+8+11[4] \\
6+8+12\end{array}$ & $\begin{array}{c}4(6)+8+10 \\
4(6)+8+12 \\
4(6)+9+11 \\
6+6+10[2] \\
6+7+10 \\
6+7+11[2] \\
6+8+10[3] \\
6+8+11[2] \\
7+7+12\end{array}$ & $\begin{array}{l}2(6)+7+12 \\
4(5)+8+10 \\
4(5)+9+11 \\
4(6)+7+8 \\
4(6)+7+9 \\
4(6)+7+10 \\
4(6)+8+11[2]\end{array}$ & $\begin{array}{l}4(6)+6+9 \\
4(6)+6+10 \\
4(6)+7+8 \\
4(6)+7+10 \\
4(6)+8+9 \\
4(6)+8+10[2] \\
6+7+10[3] \\
6+8+10[2] \\
6+8+11\end{array}$ & $\begin{array}{c}2(6)+8+10 \\
3(6)+6+9 \\
4(6)+7+8 \\
6+7+8 \\
6+7+9 \\
6+8+9 \\
6+9+11 \\
7+9+10\end{array}$ \\
\hline Supralabials & $\begin{array}{l}16[3] \\
17[2] \\
18[2]\end{array}$ & $\begin{array}{l}16[5] \\
17[5] \\
18[7] \\
19[3] \\
20\end{array}$ & $\begin{array}{l}16[11] \\
17[3] \\
19\end{array}$ & $\begin{array}{l}16[5] \\
17[3]\end{array}$ & $\begin{array}{l}16[6] \\
17[5] \\
18[2]\end{array}$ & $\begin{array}{l}16[8] \\
17[2]\end{array}$ \\
\hline Infralabials & $\begin{array}{l}20[2] \\
21[3] \\
22[2]\end{array}$ & $\begin{array}{l}20[2] \\
21[3] \\
22[15]\end{array}$ & $\begin{array}{l}20 \\
21 \\
22 \\
23\end{array}[11]$ & $\begin{array}{l}21 \\
22 \\
23\end{array}[5]$ & $\begin{array}{l}21[3] \\
22[8] \\
23[2]\end{array}$ & $\begin{array}{l}20 \\
21 \\
22 \\
24\end{array}[5]$ \\
\hline Gulars & $\begin{array}{l}3[3] \\
4[4]\end{array}$ & $\begin{array}{l}4 \text { [9] } \\
5[6]\end{array}$ & $\begin{array}{l}4[11] \\
5[3]\end{array}$ & $\begin{array}{l}3 \\
4 \\
5 \\
6\end{array}$ & $\begin{array}{l}4[6] \\
5[3]\end{array}$ & $\frac{4}{5}[5]$ \\
\hline Maxillary Teeth & $\begin{array}{l}19 \\
21[2] \\
23\end{array}$ & $\begin{array}{l}21[8] \\
22[10] \\
23 \\
24\end{array}$ & $\begin{array}{l}21[6] \\
22[3]\end{array}$ & $\begin{array}{l}21[3] \\
23\end{array}$ & $\begin{array}{l}21[8] \\
22[2]\end{array}$ & $\begin{array}{l}20 \\
21[2] \\
22[2] \\
23[2]\end{array}$ \\
\hline
\end{tabular}

${ }^{1}$ Figures in brackets indicate the number of specimens, when more than one. 
73 on the body; the only one with visible tail blotches has a total blotch count of 93. The opening in the frontoparietal band is elongate.

Chichen Itza Series.-A population of relatively short-tailed snakes with heavily keeled and numerous dorsals, large numbers of ventrals and few caudals. The blotched color pattern is retained in the adults. There are relatively few blotches; the total count ranges from 60 to 83 . The opening in the frontoparietal band is round.

Chilpancingo Series.-A population of somewhat dwarfed [?] snakes with weakly keeled dorsals and few ventrals and caudals. The juvenile pattern is lost in the adults, which are dark olive. The five young show total blotch counts of 80 to 104, with an average of about 92 . The opening in the frontoparietal band is elongate.

Acahuizotla Series.-A population of relatively long-tailed snakes with weakly keeled dorsals and large numbers of ventrals and caudals. The juvenile color pattern is lost in the adults, which are unicolor green. Ralph W. Axtell wrote concerning these (in litt.): "We collected five or more ... Elaphe chlorosoma-three with very vivid juvenile coloration ... and two adults with a much darker green coloration than any other chlorosoma I have ever seen: it was deep olive, which in no way resembles the greenish-gray of other living specimens I have observed [from farther north]." The five young show total blotch counts of 87 to 104 . The opening in the frontoparietal band is elongate.

Tehuantepec Series.-A population of relatively long-tailed snakes with weakly keeled dorsals and large numbers of ventrals and caudals. The blotched color pattern is lost in the adults, which are unicolor (? olive-) green. The three young show total blotch counts varying from 89 to 101 . The opening in the frontoparietal band is elongate.

Central American Series.-A population of moderately short-tailed snakes with strongly keeled dorsals in small number, large number of ventrals, but only a moderate number of caudals. The juvenile color pattern is lost in the adults, which are unicolor light tan. The four young show total blotch counts of 64 to 78 . The

Table IV. Meristic Characters of Series of Elaphe triaspis

\begin{tabular}{|c|c|c|c|c|c|c|}
\hline Locality & No. & Total Dorsals & Ventrals & Subcaudals & Body Blotches & Total Blotches \\
\hline
\end{tabular}

\section{MALES}

\begin{tabular}{|c|c|c|c|c|c|c|}
\hline Arizona & 5 & $\begin{array}{c}83-86 \\
M=84.0\end{array}$ & $\begin{array}{c}254-260 \\
M=257.4 \pm 1.2\end{array}$ & $M=121-122$ & 69 & - \\
\hline Chichen Itza & 10 & $\begin{array}{c}83-87 \\
M=84.0\end{array}$ & $\begin{array}{c}247-262 \\
M=257.3 \pm 1.5\end{array}$ & $\begin{array}{c}100-112 \\
M=106.8 \pm 1.4\end{array}$ & $M=46-12 \pm 0.6$ & $\begin{array}{c}71.83 \\
M=74.8\end{array}$ \\
\hline Chilpancingo & 7 & $\begin{array}{c}78-85 \\
M=81.8\end{array}$ & $\begin{array}{c}241-248 \\
M=244.4 \pm 0.8\end{array}$ & $\begin{array}{c}105-111 \\
M=109.0_{ \pm 1.1}\end{array}$ & $M=60.5$ & $\begin{array}{r}80-104 \\
M=92.0\end{array}$ \\
\hline Acahuizotla & 6 & $\begin{array}{c}79-83 \\
M=81.3\end{array}$ & $\begin{array}{c}249-257 \\
M=253.7 \pm 1.3\end{array}$ & $M=124.3$ & $M=59.5$ & $\begin{array}{r}93-104 \\
M=97.3\end{array}$ \\
\hline Tehuantepec & 8 & $\begin{array}{c}81-85 \\
M=82.5\end{array}$ & $\begin{array}{c}249-257 \\
M=254.1 \pm 1.0\end{array}$ & $\begin{array}{c}119-126 \\
M=122.8 \pm 1.1\end{array}$ & $M=56.5$ & $\begin{array}{r}97-101 \\
M=99.0\end{array}$ \\
\hline $\begin{array}{l}\text { Central } \\
\text { America }\end{array}$ & 8 & $\begin{array}{c}73-82 \\
M=79.1\end{array}$ & $\begin{array}{c}247-264 \\
M=257.6 \pm 1.2\end{array}$ & $M=112.5 \pm 0.8$ & $M=51.8$ & $\begin{array}{c}71-78 \\
M=74.3\end{array}$ \\
\hline \multicolumn{7}{|l|}{ EMALES } \\
\hline Arizona & 2 & $\begin{array}{c}91-92 \\
M=91.5\end{array}$ & $\begin{array}{l}272-273 \\
M=272.5\end{array}$ & $M=104.5$ & 73 & 93 \\
\hline Chichen Itza & 12 & $\begin{array}{c}85-95 \\
M=89.1\end{array}$ & $\begin{array}{c}261-273 \\
M=268.8 \pm 1.1\end{array}$ & $\begin{array}{c}87-97 \\
M=93.6 \pm 1.1\end{array}$ & $\begin{array}{c}\quad 43-57 \\
M=48.8 \pm 1.0\end{array}$ & $\begin{array}{c}60-78 \\
M=68.3\end{array}$ \\
\hline Chilpancingo & 9 & $\begin{array}{c}81-93 \\
M=87.1\end{array}$ & $\begin{array}{c}256-271 \\
M=264.9 \pm 1.6\end{array}$ & $M=\begin{array}{l}89-94 \\
M=91.3\end{array} 0.7$ & $M=61-67$ & $\begin{array}{c}86-97 \\
M=92.0\end{array}$ \\
\hline Acahuizotla & 2 & 87 & $\begin{array}{c}274-281 \\
M=277.5\end{array}$ & $M=108.0$ & 58 & 87 \\
\hline Tehuantepec & 5 & $\begin{array}{c}85-91 \\
M=87.0\end{array}$ & $\begin{array}{c}266-280 \\
M=274.4 \pm 3.0\end{array}$ & $M=\frac{93-105}{M=100.6} \pm 1.2$ & 59 & 89 \\
\hline $\begin{array}{l}\text { Central } \\
\text { America }\end{array}$ & 2 & $\begin{array}{c}81-83 \\
M=82.0\end{array}$ & $\begin{array}{c}265-279 \\
M=272.0\end{array}$ & $\begin{aligned} & 96-101 \\
M & =98.5\end{aligned}$ & 45 & 64 \\
\hline
\end{tabular}


opening in the frontoparietal band is elongate, and the band is generally broken near the anterior end of the parietals.

As indicated by the description above (and Text-fig. 6), these various populations fall into three main groups on the basis of adult color. Correlated features of body proportions and scutellation also suggest these basic divisions (Table IV). The divisions are meaningful from a geographic standpoint as well: the snakes of the lowlands of the Yucatan Peninsula forming one, the snakes of the highlands of Central America another, and the snakes from the edges of the Mexican Plateau and adjacent highlands still another. These groups are discussed below.

\section{Yucatan Peninsula}

The Chichen Itza series is the most distinctive, differing from all others in the retention of the blotched color pattern throughout life and in the possession of a round opening in the frontoparietal band (Text-fig. 9a). It also differs from all series except that from Central America in the more heavily keeled dorsal scales and in the lower number of dorsal blotches. It has fewer caudals than any series except that from Chilpancingo, and is distinctive in this respect (without overlap) from three of the other five series. A large number of dorsals is present (Table IV); a feature completely distinguishing this series from the Central American snakes.

Of the other snakes from the state of Yucatán (Text-fig. 7), one (AMNH 38845 from Tekat) retains the blotched color pattern at a body length of $611 \mathrm{~mm}$. The other two (from Mayapan and Merida) are juvenile, but all agree with the Chichen Itza series in blotch number, the round opening of the frontoparietal band, and the total dorsal counts (Table V). The female has an incomplete tail, but one of the males (CNHM 40722 from Mayapan) has a subcaudal count that falls near the mean for the Chichen Itza series (107); the other (CNHM 20603 from Merida) has fewer (95) than shown by that series.

Three males and two females from Felipe

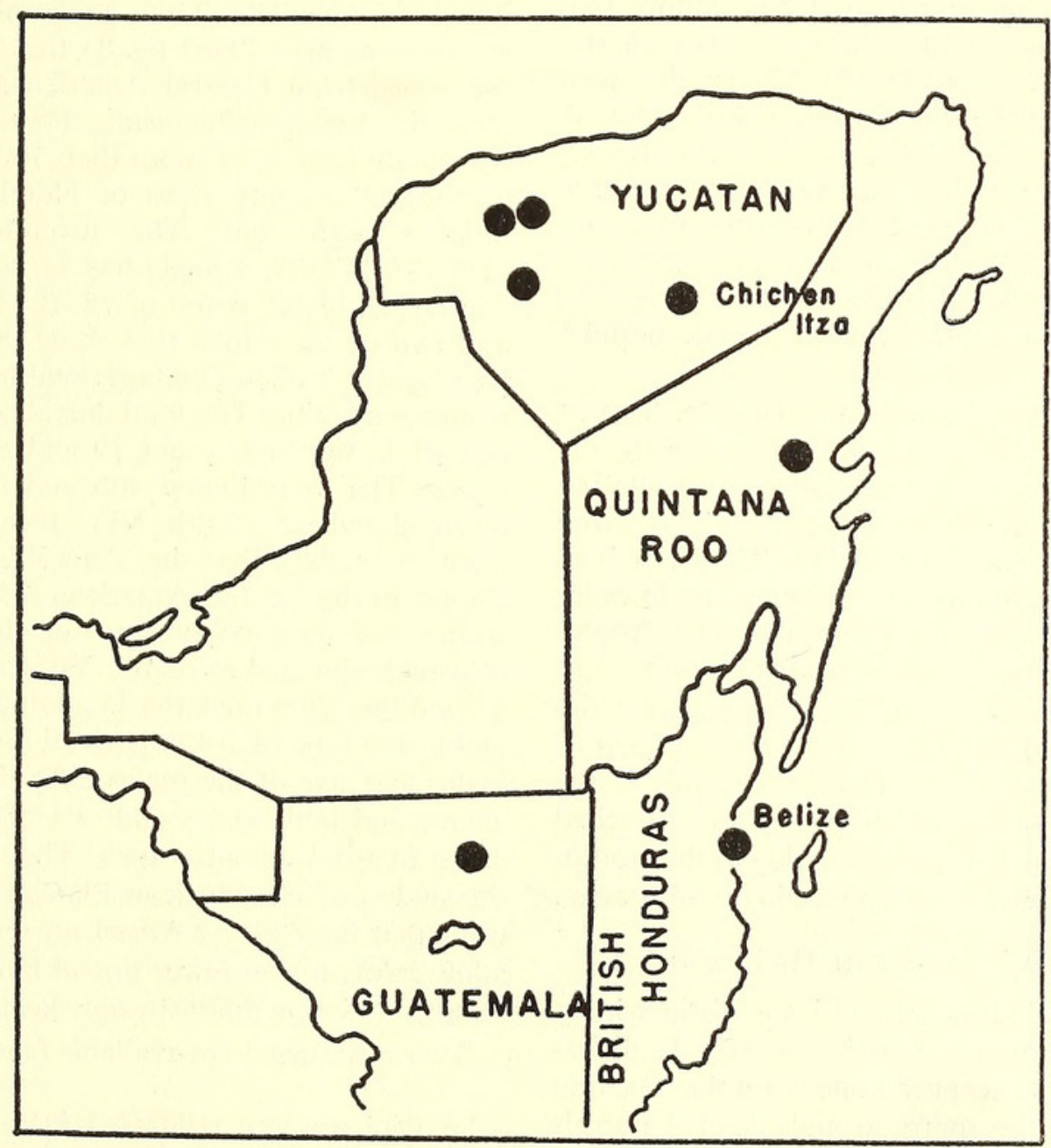

Texr-FIG. 7. Map of the Yucatan Peninsula showing the localities from which specimens of Elaphe $t$. triaspis have been available. Belize, British Honduras, is the type locality of this subspecies. 
Table V. Characteristics of Specimens from the Yucatan Peninsula

\begin{tabular}{|c|c|c|c|c|c|c|}
\hline & No. & $\begin{array}{c}\text { Total } \\
\text { Dorsals }\end{array}$ & Ventrals & Subcaudals & $\begin{array}{c}\text { Body } \\
\text { Blotches }\end{array}$ & $\begin{array}{c}\text { Total } \\
\text { Blotches }\end{array}$ \\
\hline \multicolumn{7}{|l|}{ MALES } \\
\hline $\begin{array}{l}\text { Chichen Itza } \\
\text { Merida } \\
\text { Mayapan } \\
\text { Felipe Carrillo } \\
\text { Uaxactun } \\
\text { Belize } 1\end{array}$ & $\begin{array}{r}10 \\
1 \\
1 \\
3 \\
1 \\
1\end{array}$ & $\begin{array}{c}83-87 \\
87 \\
83 \\
83-87 \\
88 \\
85\end{array}$ & $\begin{array}{c}247-262 \\
254 \\
257 \\
250-257 \\
250 \\
260\end{array}$ & $\begin{array}{c}100-112 \\
95 \\
107 \\
101 \\
107 \\
108\end{array}$ & $\begin{array}{c}46-52 \\
48 \\
47 \\
42-50 \\
55 \\
50\end{array}$ & $\begin{array}{l}71-83 \\
74 \\
72 \\
83 \\
80\end{array}$ \\
\hline \multicolumn{7}{|l|}{ FEMALES } \\
\hline $\begin{array}{l}\text { Chichen Itza } \\
\text { Tekat } \\
\text { Felipe Carrillo }\end{array}$ & $\begin{array}{r}12 \\
1 \\
2\end{array}$ & $\begin{array}{l}85-95 \\
89 \\
89-91\end{array}$ & $\begin{array}{c}261-273 \\
270 \\
271-281\end{array}$ & $\begin{array}{c}87-97 \\
+ \\
87\end{array}$ & $\begin{array}{c}43-57 \\
52 \\
48\end{array}$ & $\frac{60-78}{65}$ \\
\hline
\end{tabular}

${ }^{1}$ Type of Coluber triaspis Cope.

Carrillo Puerto, Quintana Roo, also agree with the Chichen Itza series in most respects. Three are adult and have retained the blotched pattern. All agree with the Chichen Itza series in blotch number, the round opening of the frontoparietal band and the total dorsal count. Two specimens have complete tails, a male with 101 subcaudals and a female with 87 agreeing with the Chichen Itza series in this respect also. A single female differs from the Chichen Itza series in ventral number, having 281 . This is the only difference noted. However, the other female also has a ventral number above the average, and it appears that this is a real difference, although a minor one, between the two populations.

Two other specimens from near the base of the Yucatan Peninsula also agree with the Chichen Itza series (USNM 24903, from Belize, British Honduras, and USNM 64906 from Uaxactun, Petén, Guatemala). They are both juvenile males, but agree with the series in every observable character (Table V). The frontoparietal band has a round opening in both.

Nomenclatural Note.-The specimen from Belize (USNM 24903) is the type specimen of Coluber triaspis Cope, 1866. Since this is the oldest name, this population-group of blotched snakes possessing a round opening in the frontoparietal band makes up the nominate subspecies.

\section{Central American Highlands}

The Central American series is distinct in its adult color pattern, a unicolor tan. It differs from all series except the one from the Yucatan Peninsula in the more strongly keeled dorsals and the lower number of dorsal blotches in the juveniles. It also differs from the series of the Yucatan Peninsula in the possession of a broken frontoparietal band with an elongate opening and in having few dorsal scales. It thus differs in at least two unrelated respects from the snakes of other areas.

Four snakes are from "Vera Paz," in the highlands of Guatemala. Thus, geographically, they are from an area (Text-fig. 8) that lies between the series from Central America and the one from the Yucatan Peninsula. Three are adults, with body lengths of more than $700 \mathrm{~mm}$. None of these show any signs of blotches, but are unicolor light tan. The juvenile specimen (USNM 24730), a male, has 51 body blotches and a total blotch count of 78. It (Text-fig. 9b) and two of the adults that show the head pattern have a broken frontoparietal band with an elongate opening. The total dorsal counts are 77 and 81 in the males, and 79 and 87 in the females. The ventral and subcaudal counts are given elsewhere (Table VI). It may be seen from these data that the Vera Paz snakes are similar to the Central American series in all respects, and show no evidence of close relationship with the snakes of the Yucatan lowlands. They differ from the latter in adult color pattern and in the type of frontoparietal band; both females and one of the males differ in subcaudal count, and both males and one of the females differ in total dorsal counts. They differ from the snakes of the Mexican Plateau in the same ways that the Central American series does: in adult color, in the fewer dorsal blotches of the young and in the more strongly keeled scales.

Two specimens ${ }^{1}$ are available from the Pacific

1 A third specimen (UMMZ 119719) has come to hand while this paper was in press. It is a juvenile female with a broken frontoparietal band, 85 total blotches and 82 total dorsals. Thus its intermediate features agree with the other two specimens. 


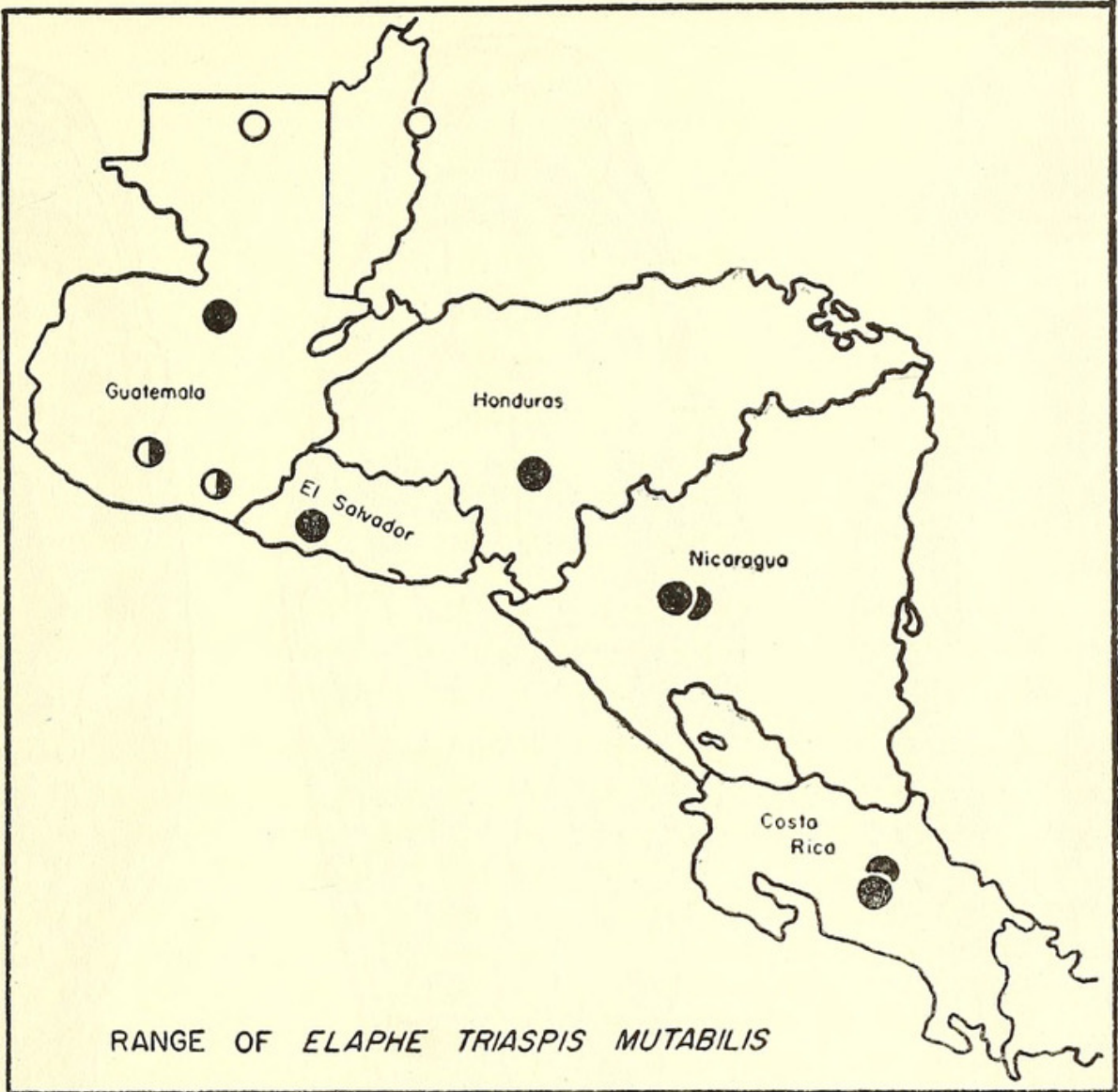

Text-Fig. 8. Map of Central America showing the localities from which specimens of Elaphe triaspis mutabilis Cope are available, and the nearest localities for other forms. "Vera Paz" is the type locality for E. triaspis mutabilis. (Solid spots=E. $t$. mutabilis, open spots=E. $t$. triaspis, half-shaded spots $=E$. $t$. intermedia $\times E$. $t$. mutabilis intergrades).

slope of the Guatemalan highlands. A juvenile female (UMMZ 102560) agrees with the Central American snakes in blotch number and total dorsal number (Table VI), but differs from them and agrees with the Tehuantepec series in ventral and subcaudal numbers, as well as in the type of frontoparietal band, which is complete. The other specimen (UMMZ 102561) is an adult female. It is unicolor but so badly darkened with strong formalin that the original color cannot be determined. The head pattern is visible, and is broken near the anterior edge of the parietals. It appears to agree best with the Acahuizotla and Tehuantepec series in scale counts (Table IV), but the head pattern is similar to that of the Central American snakes. It has 13 keeled dorsals at midbody, which also suggests affinities with the Central American snakes.

Nomenclatural Note. - The snakes from "Vera Paz" include the holotype of Coluber mutabilis Cope, 1885 . Therefore these snakes, which have few blotches and few dorsals, an elongate opening in a usually broken frontopa- rietal band, and become uniform tan as adults, may be called Elaphe triaspis mutabilis Cope.

\section{Mexican Highlands}

Northward and westward from Guatemala the highlands break up into a number of smaller peaks and ranges. Only a single specimen, a juvenile female (USNM 46512), is available from this region south of the Isthmus of Tehuantepec (Text-fig. 10). It is from Chilon, Chiapas (Table VII), and might be expected to show relationship with either the Central American snakes or those from the Yucatan Peninsula. Actually, it does not, but instead agrees well with the series from the vicinity of Tehuantepec (Table IV). Its head pattern is similar to the snakes from farther north and west, and the large number of dorsal blotches (95) distinguishes it effectively from either of the previously described population-groups.

The Tehuantepec series agrees well with the series from Acahuizotla and from Arizona (Table IV). The only observable differences between them appear to be a reflection of the 

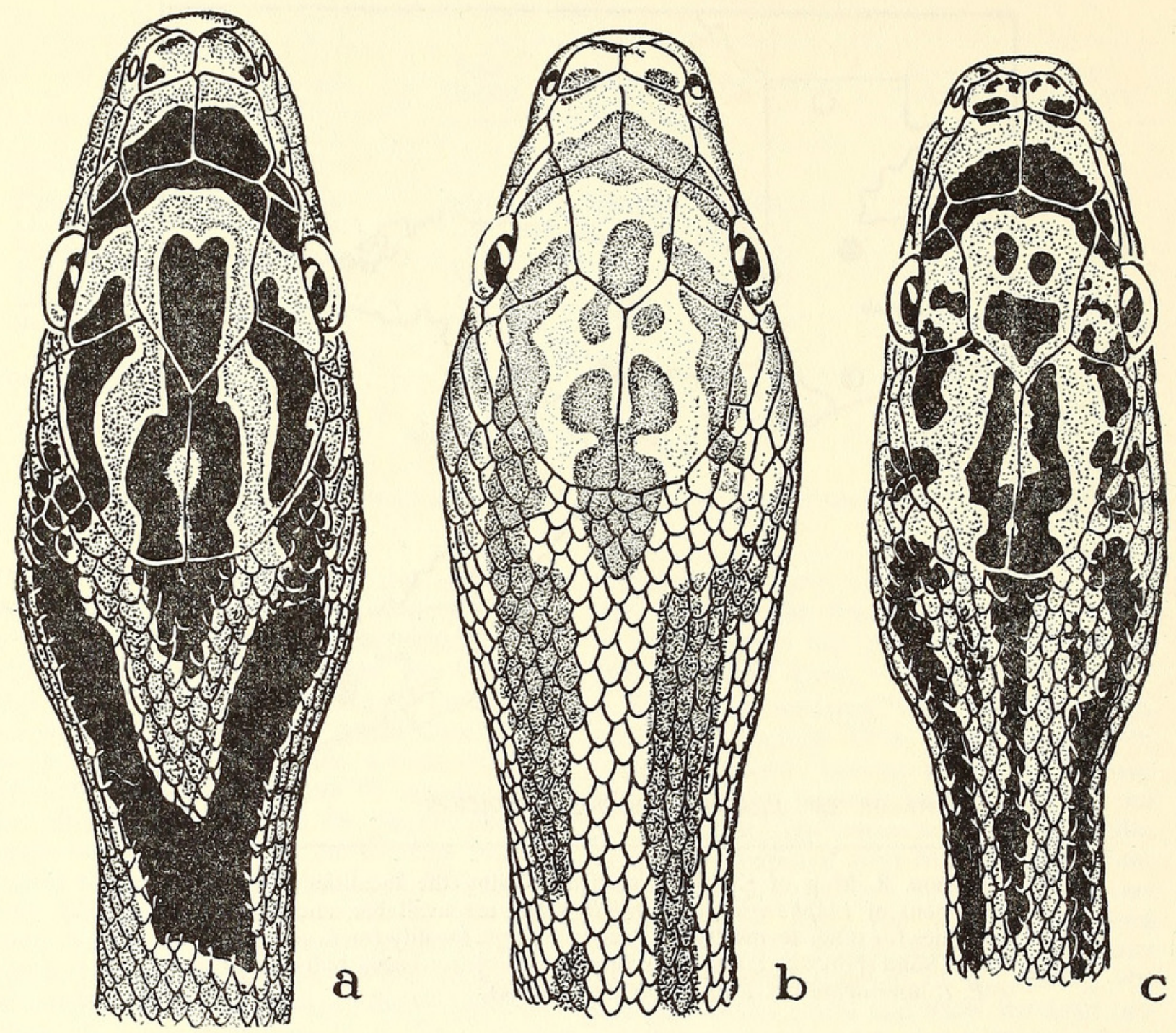

TeXT-FIG. 9. Subspecific variation in the head pattern of Elaphe triaspis as shown in juvenile individuals: a. E. t. triaspis, b. E. triaspis mutabilis, c. E. triaspis intermedia. The small rounded opening in the median frontoparietal band in "a" is diagnostic of that subspecies.

small number of specimens from any one locality. Therefore, they may be combined into a single series characterized by numerous blotches in the young and a uniform green coloration in adults, a frontoparietal band that is usually unbroken posterior to the frontal and with an elongate opening (Text-fig. 9c), and large numbers of ventrals and subcaudals (Table VII).

Four males and two female specimens are available from Colima. The total blotch counts of the females, 82 and 83 , are lower than the minimum observed in the combined series, but not unexpectedly so considering the small number of observations. Three of the Colima specimens have unbroken frontoparietal bands with elongate openings, two have the band broken. The two adult males are uniform gray (= green in life). One of the males (MCZ 37156) has a ventral count (247) that is slightly below the minimum observed in the combined series
(249), but the other counts are within that range (Table VII).

Among the other specimens, only the Chilpancingo series and a few scattered records described below differ from the combined series to any appreciable degree (Tables IV, VII).

The characters of the Chilpancingo series present a problem that is of both biological and nomenclatural importance. This series, with other scattered specimens from the Balsas Valley (hereafter called the Balsas population), differs completely in ventral and subcaudal numbers from the Acahuizotla series and other snakes from the Pacific slope of the Sierra Madre del Sur (Tables IV, VII). Yet Chilpancingo and Acahuizotla are only about 15 miles apart (Textfig. 11). On the other hand, the Acahuizotla series agrees completely with the Tehuantepec series (some 300 miles to the south), and very closely with the Arizona series (over 1,000 
Table VI. Characteristics of Specimens from Central America

\begin{tabular}{|c|c|c|c|c|c|c|}
\hline & No. & $\begin{array}{c}\text { Total } \\
\text { Dorsals }\end{array}$ & Ventrals & Subcaudals & $\begin{array}{c}\text { Body } \\
\text { Blotches }\end{array}$ & $\begin{array}{c}\text { Total } \\
\text { Blotches }\end{array}$ \\
\hline \multicolumn{7}{|l|}{ MALES } \\
\hline $\begin{array}{l}\text { Vera Paz } 1 \\
\text { El Salvador } \\
\text { Honduras } \\
\text { Nicaragua } \\
\text { Costa Rica }\end{array}$ & $\begin{array}{l}2 \\
2 \\
2 \\
1 \\
3\end{array}$ & $\begin{array}{c}77-81 \\
? \\
81 \\
79 \\
73-82\end{array}$ & $\begin{array}{c}249-255 \\
261-264 \\
257-264 \\
255 \\
247-259\end{array}$ & $\begin{array}{c}107-115 \\
112-115 \\
114+ \\
114 \\
110-113\end{array}$ & $\begin{array}{c}51 \\
44 \\
56 \\
51 \\
50-51\end{array}$ & $\frac{78}{\overline{78}}$ \\
\hline \multicolumn{7}{|l|}{ FEMALES } \\
\hline $\begin{array}{l}\text { Yepacapa } \\
\text { Chiquimulilla } \\
\text { Vera Paz } 1 \\
\text { Nicaragua } \\
\text { Costa Rica }\end{array}$ & $\begin{array}{l}1 \\
1 \\
2 \\
1 \\
1\end{array}$ & $\begin{array}{c}81 \\
85 \\
79-87 \\
81 \\
83\end{array}$ & $\begin{array}{c}269 \\
272 \\
280-282 \\
265 \\
279\end{array}$ & $\begin{array}{c}94 \\
97+ \\
100-109 \\
96 \\
101\end{array}$ & $\frac{53}{-}$ & $\frac{77}{-}$ \\
\hline
\end{tabular}

${ }^{1}$ Type series of Coluber mutabilis Cope.

miles to the north), in these features as well as others (Table IV).

However, the numbers of ventrals and subcaudals are the only differences found between the Balsas population and the other major series. Further, when specimens from areas other than those from which series are available are considered, some are found to bridge these differences. Three specimens from Puebla (outside the Balsas Valley) agree with the Balsas popula- tion in ventral number but apparently have a larger number of subcaudals (Table VII). The specimens from Colima (described above and Table VII) have only slightly higher numbers of ventrals and subcaudals than those from the Balsas Valley. Lastly, a specimen from as far away as Sinaloa (UMMZ 114600) agrees with the Balsas population in subcaudal number (and apparently in ventral number as well, although the ventral series has a small break, Table VII),

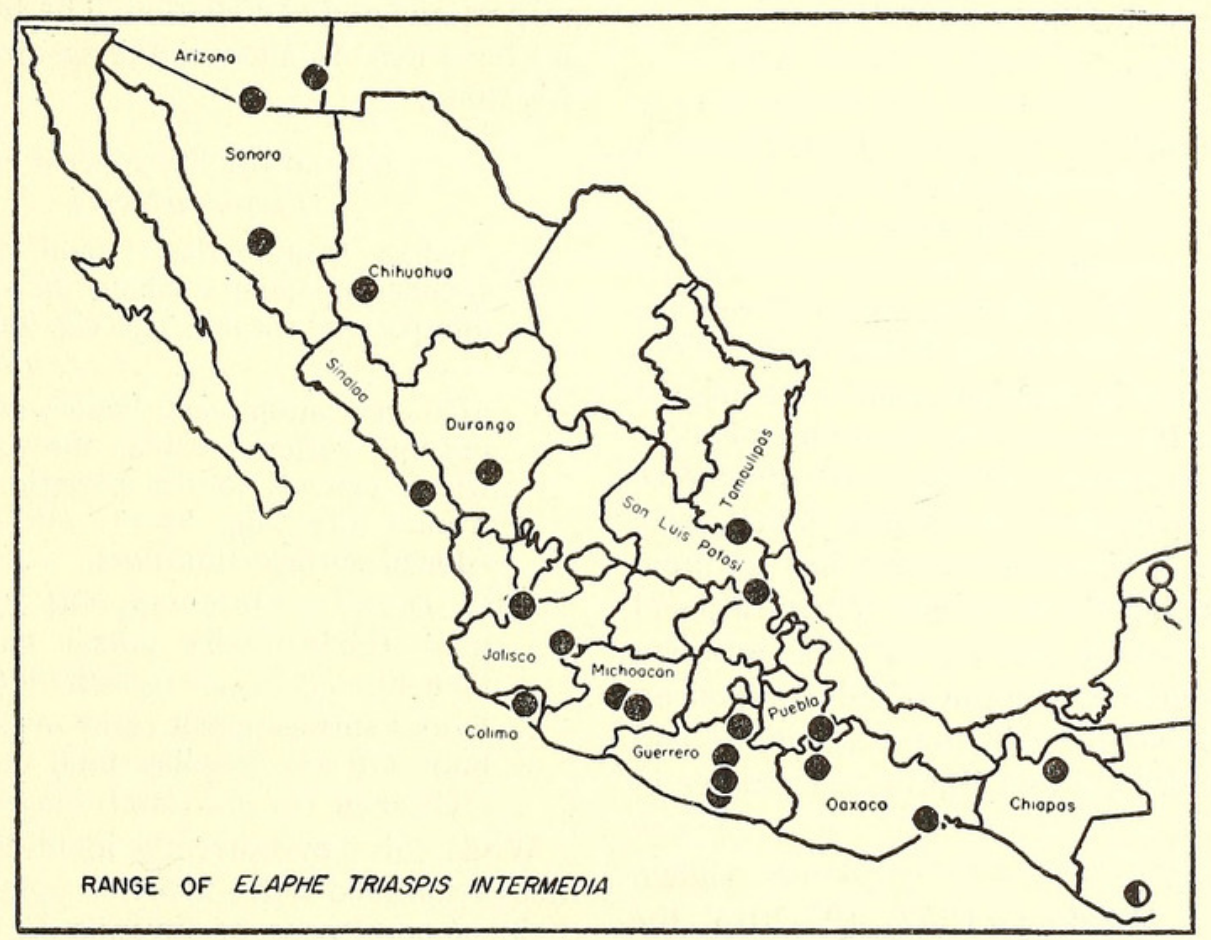

Text-FIg. 10. Map of Mexico and adjacent regions showing the localities from which specimens of Elaphe triaspis intermedia Boettger are available. See Text-fig. 11 for details of the Chilpancingo region. (Solid spots $=E$. $t$. intermedia, half-shaded spots $=E$. $t$. intermedia $\times E$. $t$. mutabilis intergrades, open spots $=E$. $t$. triaspis. 


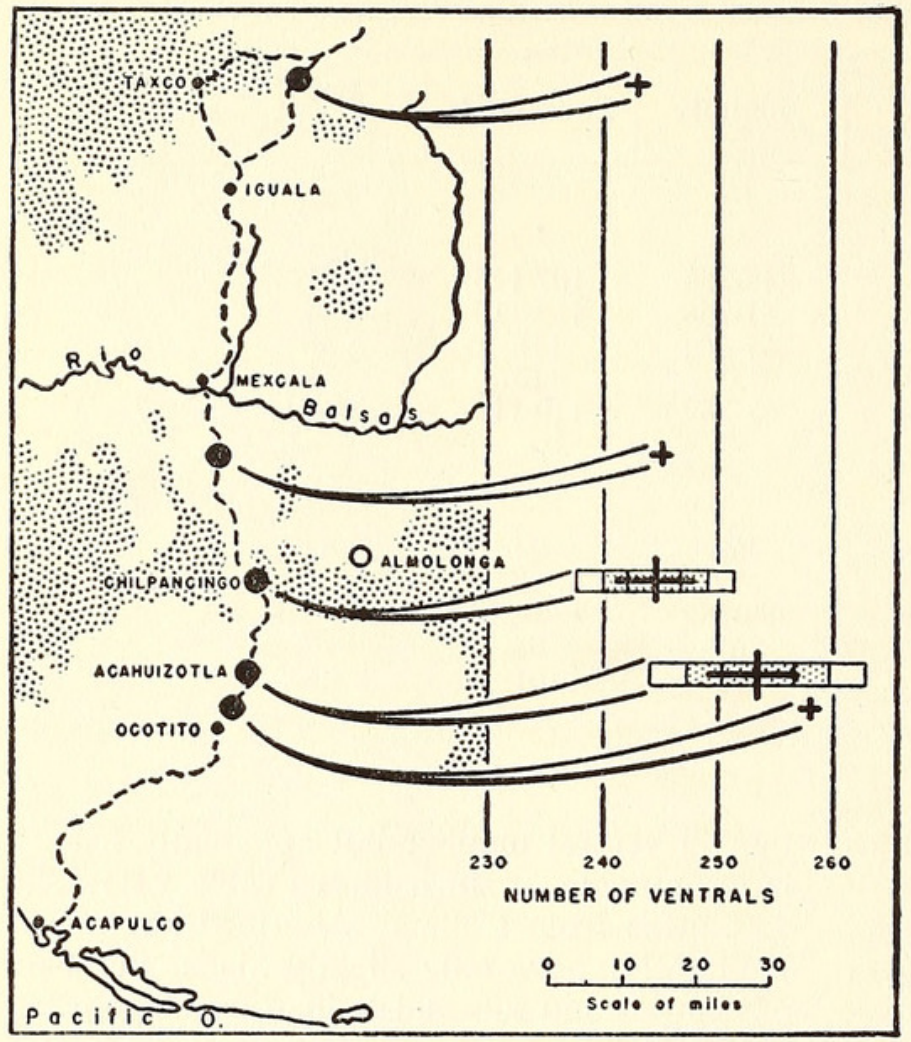

and a specimen from Apatzingán, Michoacán (UMMZ 112513), in the lower Balsas Valley, has counts typical of the coastal populations ( 260 ventrals, 117 subcaudals).

Thus, even if it were deemed advisable to describe subspecies on the basis of ventral and subcaudal numbers only (and I do not believe it is), it seems premature to apply a name to the Balsas population at this time (although one is already available, vide infra). The clear-cut distinction between the Chilpancingo and Azahuizotla series is very striking, and is undoubtedly correlated with the environmental differences: the xeric thorn scrub of the Balsas Valley contrasted with mesic tropical rainforest of the Pacific slope. It may be that the two ends of a circle of populations which are otherwise clinally related meet here, or it may be that some factor in the xeric environment has a direct effect in reducing the numbers of ventrals and subcaudals. Further analysis of this problem must await a greater amount of information on the extent of variation in the populations and correlated ecological and life history studies in the field.

Nomenclatural Note.-As previously shown by Mertens \& Dowling (1952: 197-201), the type specimen of Pityophis intermedius Boettger, 1883, agrees with the snakes of the Mexican highlands. Since this is the oldest available name for these snakes, they are to be called Elaphe triaspis intermedia Boettger.
TEXT-FIG. 11. Map of southeastern Guerrero, Mexico, showing the narrow zone between specimens with high ventral and subcaudal counts (Acahuizotla) and those with low counts (Chilpancingo). The town of Almolonga (=Amula) is the type locality of Coluber chlorosoma Günther, as here restricted. Shaded areas in the map are above 1,500 meters in altitude. The number of ventrals is plotted as a + mark for isolated specimens. For the series, the observed range is shown as a heavy horizontal line and the mean as a vertical line. Three standard deviations are plotted as rectangles on either side of the mean, with the first two shaded to emphasize the expected overlap between the snakes of these populations, even though there is no overlap shown by the two small series available. Males only are plotted; the females show about the same amount of difference.

\section{TAXonomic Section}

As indicated in the previous section, Elaphe triaspis Cope may be divided into three geographic subspecies that differ from one another mainly in color pattern, but also differ in body proportions and scutellation. The following key has been used to allocate the specimens used in this study.

Key to the Subspecies of Elaphe triaspis

1. Median frontoparietal band with a small rounded opening at about the middle of the interparietal suture (Text-fig. 9a) .......... .............. t. triaspis (p. 71).

1'. Median frontoparietal band with an elongate opening (often breaking through the band) which extends to the posterior end of the frontal (Text-fig. 9b-c); OR band absent (dorsal surface unicolor) ............

$2\left(1^{\prime}\right)$. Dorsal surface tan; OR (in juveniles) total (body + tail) dorsal blotches fewer than $80 \ldots . . \ldots$. E. triaspis mutabilis (p. 72)

2 '. Dorsal surface green (gray or bluish in alcohol) ; OR (in juveniles total dorsal blotches more than 79..E. triaspis intermedia (p. 73)

While this key correctly identified all specimens examined here, it seems possible that occasional specimens of juvenile E. triaspis mutabilis and E. triaspis intermedia might sometimes be misidentified. Questionable identifications should be checked against the various items of scutellation, especially the numbers of dorsals, ventrals, and caudals. 


\section{Description of Subspecies}

The characteristics of the various geographically different forms have been described above, so here only the elements concerned with the actual taxonomic treatment of these forms are given.

\section{Elaphe triaspis triaspis (Cope)}

Coluber triaspis Cope, 1866: 128 (original description; "Belize").

Natrix triaspis (Cope), Cope, 1887: 71 (listed).

Scotophis mutabilis (Cope), Bocourt, 1888: 680-82 [partim] (description; Yucatán).

Coluber triaspis Cope, 1892: 631 (in key).Günther, 1894: 115 (listed, synonymizes $C$. mutabilis Cope, 1885).-Boulenger, 1894: 37 (description, possibly all referable to E. $t$. intermedia); 1896: 627 (scutellation; Yucatán).Gadow, 1905: 230 (northern origin).-Barbour \& Cole, 1906: 152 (quote letter from Stejneger confirming synonymy of $C$. mutabilis Cope, 1885: Chichen Itza, Yucatán).-Werner, 1929: 86 (in key).

Elaphe triaspis (Cope), Amaral, 1929: 159 (listed). Coluber triaspis Cope, Shattuck, 1933: 575-76 (listed; parasites; Chichen Itza, Yucatán).

Elaphe triaspis (Cope), Schmidt \& Andrews, 1936: 172-73 (scutellation; Merida and Chichen Itza, Yucatán) --Gaige, 1936: 299 (scutellation, hemipenis; Chichen Itza, Yucatán).-Andrews, 1937:
358 (scutellation; Merida and Chichen Itza, Yucatán).-Smith, 1941: 134 (color pattern, confirms synonymy of $C$. mutabilis Cope, 1885).Schmidt, 1941: 500 (scutellation of type; British Honduras).-Smith, 1943: 427 [partim] (scutellation; Chichen Itza, Yucatán). Smith \& Taylor, 1945: 60-61 (range in Mexico).-Smith \& Taylor, 1950: 316 (type locality restricted to town of Belize, British Honduras).

Elaphe triaspis triaspis (Cope), Stuart, 1948: 69 (recognized relationship with $C$. mutabilis (Cope).-Mertens \& Dowling, 1952: 201 (listed). -Dowling, 1952b: 7 (listed).-Peters, 1953: 228 (new state record; Quintana Roo).

Definition.-A subspecies of Elaphe triaspis characterized by a medial frontoparietal band with a small rounded light spot at about the middle of the interparietal suture (Text-fig. 9a), and by the retention of a blotched pattern throughout life.

Location of Type and Type Locality.-The type specimen (USNM 24903) was collected at "Belize" by Dr. Parsons. He is not known to have collected anywhere in British Honduras except in the vicinity of the town of that name, and the specimen was probably collected there. For this reason the prior restriction (Smith \& Taylor, 1950: 316) of the type locality to the vicinity of the town of Belize, British Honduras, is considered valid.

Table VII. Characteristics of Specimens from Mexico Excluding the Yucatan Peninsula

\begin{tabular}{l|c|c|c|c|c|c}
\hline \hline & No. & $\begin{array}{c}\text { Total } \\
\text { Dorsals }\end{array}$ & Ventrals & Subcaudals & $\begin{array}{c}\text { Body } \\
\text { Blotches }\end{array}$ & $\begin{array}{c}\text { Total } \\
\text { Blotches }\end{array}$ \\
\hline
\end{tabular}

\section{MALES}

\begin{tabular}{|c|c|c|c|c|c|c|}
\hline Combined Series & 19 & $79-86$ & $249-260$ & $119-126$ & $54-69$ & $93-104$ \\
\hline Tamaulipas & 1 & 80 & 251 & 123 & 71 & 104 \\
\hline "Mexico" 1 & 1 & 83 & 254 & 117 & 53 & 90 \\
\hline Sinaloa & 1 & 78 & $243 ?$ & 103 & - & - \\
\hline Durango & 1 & 83 & 253 & 110 & - & - \\
\hline Jalisco & 1 & 81 & 258 & 125 & - & - \\
\hline Colima & 4 & $80-83$ & $247-251$ & $121-124$ & 62 & 104 \\
\hline Michoacan & 5 & $83-85$ & $249-260$ & $114-120$ & 54 & 88 \\
\hline Puebla & 1 & - & 243 & - & - & - \\
\hline Balsas Valley & 2 & $83-85$ & $243-245$ & $108-109$ & - & - \\
\hline Chilpancingo & 7 & $78-85$ & $241-248$ & $105-111$ & $55-66$ & $80-104$ \\
\hline Ocotito & 1 & 83 & 258 & 125 & - & - \\
\hline San Andres & 1 & 83 & 244 & 120 & - & - \\
\hline \multicolumn{7}{|l|}{ EMALES } \\
\hline Combined Series & 9 & $85-92$ & $266-281$ & 93-110 & $58-73$ & $87-93$ \\
\hline Tamaulipas & 4 & $87-89$ & $270-276$ & $92+-102$ & 77 & 108 \\
\hline Sonora & 1 & 90 & 281 & $99+$ & - & - \\
\hline Chihuahua & 2 & $85-91$ & 278 & 103 & - & - \\
\hline Jalisco & 1 & 95 & 263 & 92 & - & - \\
\hline Colima & 2 & $83-91$ & $266-271$ & $94-99$ & 56 & $82-83$ \\
\hline Puebla & 2 & $87-89$ & $266-268$ & $94-100$ & - & - \\
\hline Chilpancingo & 9 & $81-93$ & $256-271$ & $89-94$ & $61-67$ & $86-97$ \\
\hline Chiapas & 1 & 83 & 274 & 97 & 63 & 95 \\
\hline
\end{tabular}

${ }^{1}$ Type of Pityophis intermedius Boettger. 
Description of Type Specimen.-The type specimen of Coluber triaspis Cope is a juvenile male. The head scutes are normal except the left loreal is divided into three, the right into two scutes; preoculars 1-1; postoculars 3-2; temporals $3+4+5$ and $3+4+6$; supralabials $8-8$, infralabials 11-10; gulars 4 . The dorsal scale count is $29+35+21$; ventrals 260 ; subcaudals 109. All dorsal rows are smooth at midbody, but nine middorsal rows above the cloacal opening are faintly keeled. There are 50 dorsal body blotches and about 30 on the tail. The body is almost cut in two anteriorly, making exact measurement impossible, but the body length is about $360 \mathrm{~mm}$.; tail length 95 ; head length 18.3; eye length 2.6.

Range.-The Yucatan Peninsula; known from Chichen Itza and Merida southward to Belize, and Uaxactun in the Petén of Guatemala.

Discussion.-A total of 32 specimens, representing six localities, was available for study (vide "Specimens Examined" below). The entire series is rather homogeneous, with some suggestion of increased ventral numbers (at least in the females) in Quintana Roo (Table V).

A summary of the characteristics of this subspecies follows. The males (17) have body lengths of $316-790 \mathrm{~mm}$. (396-1,023 mm. in total length), tail equals 28-29 per cent. of body length in adults, eye equals $12-15$ per cent. of head length in adults, $1-2$ preoculars, $2-3$ postoculars, $1(3)+3+4$ to $3+4+6$ temporals, $8-10$ supralabials, $10-11$ infralabials, $29+33+21$ to $31+37+23$ dorsals, 247-262 ventrals, 95-112 subcaudals, $42-55$ body blotches, $71-83$ total blotches. The females (15) have body lengths of $318-912 \mathrm{~mm}$. $(385-1,112+\mathrm{mm}$. in total length), tail equals 23-24 per cent. of body length in adults, eye equals $12-15$ per cent. of head length in adults, 1 preocular, $2-3$ postoculars, $2(3)+3+4$ to $3+4+6$ temporals, $8-10$ supralabials, $10-11$ infralabials, $29+33+23$ to $33+39+23$ dorsals, 261-281 ventrals, 87-97 subcaudals, $43-57$ body blotches, $60-78$ total blotches.

No specimens have been seen from areas where intergrades between this subspecies and adjacent forms would be expected (Text-fig. 7). The specimen from Uaxactun (USNM 64906) has a number of body blotches (55) that equals the maximum found in the Chichen Itza series, as does its total blotch count (83). It may thus show some approach toward E. triaspis intermedia to the west. However, its head pattern and other characters (Table V) are typical of E. t. triaspis.

\section{Elaphe triaspis mutabilis (Cope)}

Coluber triaspis Cope, 1879: 271 (listed; plateau near San José, Costa Rica) [non C. triaspis Cope, 1866].

Coluber mutabilis Cope, 1885: 175-76 (original description; type locality, "Vera Paz").

Natrix mutabilis (Cope), Cope, 1887: 71 [partim] (listed; Costa Rica, Vera Paz).

Scotophis mutabilis (Cope), Bocourt, 1888: 680-82 [partim], pl. xlvi, figs. 2-2d, and [?] 2f (description; Vera Paz).

Coluber mutabilis Cope, 1892: 631 [partim] (in key).

Coluber triaspis Cope, Boulenger, 1894: 37 [partim] synonymizes $C$. mutabilis Cope, 1885) [non $C$. triaspis Cope, 1866].

Coluber polylepis Werner, 1896: 247-48, pl. 6, figs. 3a-c (original description; type locality, "Honduras").

Coluber mutabilis Cope, 1900: 855-57 [partim] (description; Vera Paz, Costa Rica).

Coluber triaspis Cope, Barbour \& Cole, 1906: 152 (quote letter from Stejneger confirming synonymy of C. mutabilis Cope, 1885) [non C.triaspis Cope, 1866].

Elaphe triaspis (Cope), Smith, 1941: 134-35 (confirms synonymy of $C$. mutabilis Cope, 1885) [non C. triaspis Cope, 1866].

Elaphe triaspis mutabilis (Cope), Stuart, 1948: 68-70 (scutellation of type specimens from Guatemala, recognized relationships).

Elaphe triaspis (Cope), Taylor, 1951: 98 (description, scutellation of paratype of C. mutabilis Cope from Costa Rica) [non C. triaspis Cope, 1866].

Elaphe triaspis intermedia, Mertens, 1952a: 93 (listed; new record; El Salvador) [non Pityophis intermedius Boettger].

Elaphe triaspis mutabilis (Cope), Mertens \& Dowling, 1952: 201 (listed).-Dowling, 1952b: 7-8 (listed).-Mertens, 1952b: 64 (description; El Salvador).

Definition.-A subspecies of Elaphe triaspis in which the juveniles have fewer than 80 total (body plus tail) blotches, and have a median frontoparietal band with an elongate central opening-the band usually broken at the frontoparietal suture (Text-fig. 9b). The adults are uniform light brown dorsally.

Location of Type Specimen, and Type Locality.-The holotype is USNM 6745 (not 6735, as given in the original description), collected in "Vera Paz" (vide infra), Guatemala, by Henry Hague. Of the six paratypes, three (USNM 6166, 24729-30) are also from Vera Paz and one (USNM 9777) is from the vicinity of San José, Costa Rica. The remaining two are referable to E. triaspis intermedia. One of these, 
collected by Dugès in "Guanajuato" is apparently the one labeled "Mexico" in the United States National Museum (USNM 11354). The other, collected by Sumichrast from the "Central or elevated part of the state of Tehuantepec," has not been located, but the area from which it was taken is in the range of E. triaspis intermedia.

Although the exact locality of the "Vera Paz" specimens cannot be established, there is good reason to believe (Stuart, 1948: 10) that they were collected on the Caribbean slope of the highlands of Coban (between Coban and Chisec ?), Alta Verapaz, Guatemala.

Description of Holotype.-An adult female with the following characters: oculars $1+2$; temporals $2(3)+3+5$ on both sides; supralabials $8-8$, 4th and 5th entering orbit; infralabials 11-11; gulars 4 . The dorsal scale count is $29+35+23$; ventrals 282 ; caudals 110 . The full scale formula is:

$$
\begin{aligned}
& 31 \frac{-7(28)}{-7(21)} 29 \frac{+7(49)}{+8(53)} 31 \frac{+8(60)}{+8(69)} 33 \\
& -31 \frac{-7(166)}{-7(169)} 29 \frac{-5(177)}{5+6(179)} 27 \frac{-6(203)}{-6(203)}
\end{aligned}
$$

The first 12 lateral rows of dorsals are smooth at midbody, the medial 11 faintly keeled. The dorsal coloration has faded to a uniform light yellowish tan (probably originally light brown) but the head pattern is visible and shows the characteristic broken medial frontoparietal band. The body is twisted, but is about $900 \mathrm{~mm}$. long; tail length 241; head length 30.3 ; eye length 4.0.

Range.-The highlands of Central America, from Guatemala southward to the vicinity of San José, Costa Rica (Text-fig. 8).

Discussion.-A total of 12 specimens representing seven localities was available for study. Certain data on two additional specimens from El Salvador were also available. The characters of this form appear to be rather constant throughout the range (Tables III, VI). However, one individual from San José, Costa Rica (MCZ 28068), the southernmost point in the range, has the lowest dorsal count found in this species: $23+29+21$. The other three Costa Rican specimens have more typical counts (midbody counts of 31,33 , and 33 ) but some reduction in dorsals is suggested.

The two specimens from the Pacific slopes of the Guatemalan highlands (Yepacapa and Chi- quimuilla) are considered to be intergrades $E$. triaspis mutabilis $\times$ E. triaspis intermedia. Omitting these two specimens, the characteristics of E. triaspis mutabilis may be summarized as follows: The males (10) have body lengths of 255-795 mm. (325-1,045 mm. in total length), tail equals $31-33$ per cent. of body length in adults, eye equals $13.5-15$ per cent. of head length in adults, 1 preocular, 2 postoculars, $1+3+5$ to $3+5+6$ temporals, $8-9$ supralabials, $10-12$ infralabials, $23+29+21$ to $27+33+21$ dorsals, 247-264 ventrals, 107-115 subcaudals, 44-56 body blotches, 71-78 total blotches. The females (4) have body lengths of 313-ca. 900 $\mathrm{mm}$. (384-ca. $1,140 \mathrm{~mm}$. in total length) tail equals 25-27 per cent. of body length in adults, eye equals $\mathrm{ca} .13$ per cent. of head length in adults, 1 preocular, $1-2$ postoculars, $1(3)+4+5$ to $3+4+5$ temporals, $8-9$ supralabials, $10-12$ infralabials, $27+31+21$ to $29+35+23$ dorsals, 265-282 ventrals, 96-109 subcaudals, 45 body blotches, 64 total blotches.

$\frac{+8(110)}{+8(104)} 35 \frac{8+9(144)}{8+9(150)} 33 \frac{5+6(160)}{6+7(161)} 31-$
$25 \frac{4+5(250)}{4+5(240)} 23(282)$

\section{Elaphe triaspis intermedia (Boettger)}

Pityophis intermedius Boettger, 1883: 148 (original description; "Mexico").

Coluber mutabilis Cope, 1885: 175-76 [partim] (listed; Oaxaca and Guanajuato).

Natrix mutabilis (Cope), Cope, 1887: 71 [partim] (listed; Tehuantepec, Guanajuato) .

Scotophis mutabilis (Cope), Bocourt, 1888: 680-82 [partim] (description; "Tehuantepec").

Coluber mutabilis Cope, 1892: 631 [partim] (in key).

Coluber chlorosoma Günther, 1894: 115-16, pl. 41 (original description; Atoyac, Veracruz, Amula, Guerrero, and San Ramón [Jalisco]).-Boulenger, 1894; 38 (description; "S. Mexico").

Coluber triaspis Cope, Boulenger, 1894: 37-38 [partim] (description; Mezquital del Oro, Zacatecas, and [?] Mexico City).

Coluber mutabilis Cope, 1900: 855-57 [partim] (listed; Oaxaca and Guanajuato).

Coluber chlorosoma Günther, Gadow, 1905: 233 (geographic dist.; Amula, Guerrero).

Elaphe chlorosoma (Günther), Stone, 1911: 231 (first record for United States; Santa Rita Mountains, Arizona) --Stejneger \& Barbour, 1917: 82 (listed).-Van Denburgh, 1922: 700-01 (described).-Stejneger \& Barbour, 1923: 90 (listed). -Blanchard, 1925: 13 (in key).-Stejneger \& 
Barbour, 1933: 98 (listed).-Oliver, 1937: 19-20 (scutellation; Colima, Colima).-Smith, 1938: 150 (differences from $E$. bairdi).-Stejneger \& Barbour, 1939: 109 (listed).-Hartweg \& Oliver, 1940: 22 (scutellation; Quiengola and Mixtequilla mountains near Tehuantepec, Oaxaca).Perkins, 1940: 7, 32 (in key).-Taylor, 1940: 461 (description; El Sabino, Michoacan, and near Chapala, Jalisco).

Elaphe mutabilis (Cope), Taylor, 1940: 459-60 (description of young; El Sabino, Michoacan) [non C. mutabilis Cope, 1885].

Elaphe chlorosoma (Günther), Taylor \& Knobloch, 1940: 129 (description; Moguarichic [=Maguarachi], Chihuahua).-Smith, 1941: 134-35 (identity of young; Colima, Colima, and El Sabino, Michoacan); 1943: 426 (scutellation; Tres Cruces, Oaxaca, and Guanajuato).

Elaphe triaspis (Cope), Smith, 1943: 427 [partim] (description; Chilon, Chiapas).

Elaphe chlorosoma (Günther), Stejneger \& Barbour, 1943: 137 (listed).-Woodbury \& Woodbury, 1944: 368 (description of young; Tehuantepec, Oaxaca).-Smith \& Taylor, 1945: 58-59 (key; range in Mexico).-Stuart, 1948: 69 (relationships).-Perkins, 1949: 9, 38 (in key).Taylor, 1949: 170 (listed; [?] San Luis Potosi). -Smith \& Taylor, 1950: 334 (type locality restricted to San Ramón, Jalisco) .-Hall, 1951: 204 (description; Chilpancingo, Guerrero).

Elaphe triaspis intermedia (Boettger), Mertens \& Dowling, 1952: 197-201 (name revived).-Dowling, 1952b: 8 (listed).

Elaphe triaspis (Cope), Martin, 1955: 173 (new state record, Tamaulipas).

Elaphe triaspis intermedia (Boettger), Alvarez del Toro \& Smith, 1956: 13 (listed; Cerro del Sumidero, $1200 \mathrm{~m}$., Chiapas).-Duellman, 1957: 238 (new state record; Sinaloa), 1958: 11 (geography; Colima).-Martin, 1958: 69 (ecology; Tamaulipas).

Definition.-A subspecies of Elaphe triaspis in which the juveniles have a median frontoparietal band with the central opening extending forward to the posterior end of the frontal scute (Text-fig. 9c), and have more than 79 total (body plus tail) dorsal blotches. The adults are unicolor green dorsally (gray or bluish in alcohol).

Location of Type Specimen, and Type Locality.-The type is in the collection of the Senckenberg Museum (SMF 34575). It is presently recorded as being from "Mexico."

Since three subspecies of Elaphe triaspis are currently recognized and others may yet be described, it seems apropos to restrict the type locality. No information appears to be available as to where Dr. Pagenstecher obtained the specimen. It was originally listed as from "Guayana" (vide Mertens \& Dowling, 1952: 198). However, its characters are matched almost ex- actly by those of the small series of snakes (EHT 5190, 5191; UIMNH 17686) from Hacienda El Sabino, Michoacan (Table VII). While some of the other series approach the characteristics of the type in some ways, this is the only one that has such a close resemblance. Thus the type locality may logically be restricted to Hacienda El Sabino, about 20 miles south of Uruapan, Michoacan, Mexico.

Description of Type Specimen.-The type is a juvenile male with a body length of $359 \mathrm{~mm}$. and a tail length of 97 . The median frontoparietal band has an elongate opening that extends forward from the middle of the interparietal suture to near the posterior end of the frontal. There are 53 body blotches, some of which are connected in zig-zag fashion (Mertens \& Dowling, 1952: fig. 1), and a total blotch count of 90 . The scale counts are: oculars $1+2$; primary temporals $2-3$, the ventral "third" temporal on the left side excluded from contact with the postoculars; supralabials 8-8, 4th and 5th entering the eye; infralabials 11-9; dorsals 31 [?] $+31+21$, smooth; ventrals 254 ; anal divided; caudals 117 pairs, some of them undivided [Data from Dr. Robert Mertens, vide Mertens \& Dowling, 1952: 198].

Range.-On the mountain slopes from southeastern Arizona and Tamaulipas southward through Mexico (but avoiding the central plateau) to Chiapas (Text-fig. 10).

Discussion.-A description of this subspecies, based on 77 specimens from 34 different localities (vide "Specimens Examined" below), may be summarized as follows: The males (45) range from $319-902 \mathrm{~mm}$. in body length (414$1,213 \mathrm{~mm}$. in total length), tail equals 31-37 per cent. of body length in adults, eye equals 13-16 per cent. of head length, 1-2 preoculars, $1-3$ postoculars, $1(3)+3+4$ to $3+4+6$ temporals, 7-9 supralabials, $9-11$ infralabials, $27+30+$ 21 to $30+35+21$ dorsals, $243-260$ ventrals, 103-126 subcaudals, 53-69 body blotches, 80104 total blotches. The females (31) range from $324-1,161 \mathrm{~mm}$. in body length (394-1,447+ $\mathrm{mm}$. in total length), tail equals 21-26 per cent. of body length in adults, eye equals 12-14 per cent. of head length in adults, 1-2 preoculars, 2 postoculars, $2+3+4$ to $3+5+6$ temporals, 8-10 supralabials, $9-12$ infralabials, $27+33+21$ to $33+39+23$ dorsals, $256-281$ ventrals, $89-110$ subcaudals, $56-77$ body blotches, $82-108$ total blotches.

As noted above (p. 68) the Chilpancingo series and other snakes of the upper Balsas Valley differ considerably in ventral and subcaudal counts from the Acahuizotla series and other specimens from the coastal slope of the Sierra 
Madre del Sur. These differences do not appear to deserve nomenclatural distinction, but a name is already available for the Balsas population if it should seem desirable to recognize it as a separate form at some future time. One of the three cotypes of Coluber chlorosoma Günther (1894) was recorded as from Amula, Guerrero, which Davis (1955: 71) has recently identified as the town now known as Almolonga, between Tixtla and Chilapa east of Chilpancingo (Textfig. 11). The type of $C$. chlorosoma does not appear to have been selected to this date (except by inference, vide infra), so I here designate the specimen from Amula (specimen " $\mathrm{b}$ " in Boulenger, 1894: 38) as the lectotype. Thus, Amula (= Almolonga), Guerrero, becomes the type locality of $C$. chlorosoma Günther by present restriction. The characteristics of the type (247 ventrals, 112 subcaudals) indicate that it belongs to the Balsas population.

The prior restriction of the type locality of C. chlorosoma to San Ramón, Jalisco (Smith \& Taylor, 1950: 334), is not recognized here on two bases: (1) the selection was apparently done mechanically, without regard to biological problems, (2) the specimen from San Ramón (specimen "c" in Boulenger 1894: 38) is represented only by the head and neck, and is thus unidentifiable if the populations with small numbers of ventrals and subcaudals should ever be recognized.

The actual provenance of the third cotype (specimen "a" in Boulenger, 1894: 38) is in question. The locality was given as "Atoyac, Vera Cruz," by Günther, but “Atoyak, Guerrero," by Boulenger. Towns of this name are located in both states, and the characteristics of the specimen ( 260 ventrals, tail incomplete) do not aid in the identification of the proper "Atoyac," though it would fit well into the coastal population in Guerrero.

Some variation in adult coloration is found in $E$. triaspis intermedia. The snakes from the northern part of the range are gray-green (vide description of Arizona specimen above) and those from the south are dark olive (vide description of Acahuizotla specimen above). This difference in coloration is not correlated with the differences in scutellation noted above, however, since the Arizona (gray-green) snakes and the Acahuizotla (dark olive) snakes are similar in scutellation, while the latter differ from the Balsas (dark olive) population in scutellation. No descriptions of the live color of the snakes of Colima have been made, but in alcohol they appear lighter than most, and may differ from both the above in adult color.

A specimen from Chilon, Chiapas (USNM
46512), is a typical representative of this subspecies (Table VII). Two specimens from the Pacific slopes of the Guatemalan highlands (described above) are recognized as intergrades $E$. triaspis intermedia $\times E$. triaspis mutabilis. No intergrades between $E$. triaspis intermedia and E. triaspis triaspis are known.

\section{SUMMARY}

The American ratsnake, Elaphe triaspis Cope, is made up of three geographic subspecies that differ mainly in adult coloration, but also differ in head pattern, blotch number, number of keeled scales and to some extent in numbers of dorsals, ventrals and subcaudals. Adults of the northern subspecies, E. triaspis intermedia Boettger, are unicolor green. This subspecies ranges from southeastern Arizona and southern Tamaulipas southward along the slopes of the Mexican highlands to Chiapas. Through most of its range it is found in montane mesophytic forest, but it has also invaded the xeric Balsas Valley and part of the dry Pacific Coast of Mexico. The southern subspecies, E. triaspis mutabilis Cope, is apparently restricted to the montane forests from the Guatemalan highlands southward to the vicinity of San José, Costa Rica. Adults are unicolor tan (greenish-tan in life). The typical subspecies, E. t. triaspis Cope, is found only on the xeric Yucatan Peninsula. The adults of this form retain the blotched pattern found in the young of all of the subspecies.

The population of E. triaspis intermedia in the Balsas Valley of southern Mexico differs from most of the other populations from which samples are available in the low numbers of ventrals and subcaudals. This apparent reduction in length, however, is the only feature in which it seems to differ, and it is not here considered to be worthy of nomenclatural recognition. Nevertheless, the type locality of Pityophis intermedius Boettger, 1883, was restricted to Hacienda El Sabino, Michoacan, because of the similarity of the type specimen to the small series of specimens available from that locality. Also the type of Coluber chlorosoma Günther, 1894, was selected from among the three cotypes: the specimen " $b$ " of Boulenger (1894: 38), from "Amula" (=Almolonga), Guerrero, which belongs to the Balsas population. Therefore, the name $C$. chlorosoma Günther is available for this population if should seem desirable to recognize it nomenclaturally at some later date.

This species is only distantly related to other American ratsnakes and agrees with other American species of Elaphe only in general features of scutellation and pattern that are also held in common with other generalized colubrid 
genera. It differs from other species of Elaphe in certain characteristics of the skull, in the type of hemipenis, in the amount of sexual dimorphism and in certain features of ontogeny. It seems likely that its closest relations are to be found among Old World species. A somewhat similar hemipenis was noted in a specimen of Elaphe longissima from Europe, but the latter differs from E. triaspis so greatly in scutellation and habitus that no close relationship is postulated on the basis of this single point of similarity.

\section{ACKNOWLEDGMENTS}

This paper is adapted and expanded from part of a dissertation submitted to the University of Michigan in 1951 (Dowling, 1952a). I wish to express my great appreciation to Norman Hartweg and Charles F. Walker, Division of Reptiles and Amphibians, and to the late J. Speed Rogers, Director of the Museum, for the privilege of working at the University of Michigan Museum of Zoology (UMMZ) and for the aid and encouragement given me. I am especially appreciative of the fine drawings used herein that were made by William L. Brudon, staff artist of that institution. Floyd L. Downs provided scale counts and data for a recently acquired specimen (UMMZ 118944) which I have not examined personally.

The latter stages of this study were aided by the financial support of the National Science Foundation (N.S.F. G-4443, G-9719). This considerable help is gratefully acknowledged.

My thanks also go to the following persons and institutions who have made specimens available and who have made other important contributions toward the completion of this study: Charles M. Bogert and Bessie M. Hecht, American Museum of Natural History, New York (AMNH); the late Emmett R. Dunn, Academy of Natural Sciences of Philadelphia (ANSP); the late Joseph R. Slevin, California Academy of Sciences, San Francisco (CalAc); the late Karl P. Schmidt, and Clifford H. Pope, Chicago Natural History Museum (CNHM); Charles H. Lowe, University of Arizona, Tucson (DZUAr); Philip J. Smith, Illinois Natural History Survey, Urbana (INHS); Edward H. Taylor, University of Kansas, Lawrence (KUMNH, EHT); Arthur Loveridge and Ernest E. Williams, Museum of Comparative Zoology, Cambridge (MCZ); Robert C. Stebbins, Museum of Vertebrate Zoology, Berkley (MVZ); Robert Mertens, Senckenberg Museum, Frankfurt (SMF); William B. Davis, Texas A. and M. College (TCWM); Hobart M. Smith, University of Illinois, Urbana (UIMNH); and Doris M.
Cochran, U. S. National Museum, Washington (USNM).

\section{SPECIMENS EXAMINED}

\section{Elaphe triaspis triaspis}

British Honduras, Belize District, Belize (USNM 24903, type).

Guatemala, Departamento Petén, Uaxactun (USNM 64906).

Mexico, Quintana Roo, Distrito Centro, Felipe Carillo Puerto (UMMZ 113600-04). Yucatán (CNHM 7007), Distrito Acanceh, Mayapan (CNHM 40722); Distrito Mérida, Mérida (CNHM 20603); Distrito Tixkokob, "Tokat" [=Tekat?] (AMNH 38845); Distrito Valladolid, Chichen Itza (AMNH 7866, 38842-44; CNHM 20624, 26970, 40723, 49345; MCZ 7250, 28751-52; UMMZ 68234-35, 83293, 83929-30; USNM 46398, 46574$77,46579)$.

\section{Elaphe triaspis mutabilis}

Costa Rica (ANSP 22376), Departamento Heredia, Cariblanco (MCZ 15270); Departamento San José, vicinity of San José (MCZ 28068; USNM 9777, paratype).

El Salvador, (SMF 43186); Departamento La Libertad, vic. Santa Tecla (SMF 43104).

Guatemala, "Vera Paz" (USNM 6745, holotype, 24729-30, 61066, paratypes).

Honduras, Departamento Tegucigalpa, Tegucigalpa (MCZ 49804-05).

Nicaragua, Departamento Matagalpa, Matagalpa (UMMZ 56496) ; 2 mi. E. San Ramón (UMMZ 116511).

\section{Elaphe triaspis intermedia}

Mexico (AMNH 19838), Chiapas, Distrito Chilon, Chilon (USNM 46512). Chihuahua, Maguarichi (UIMNH 17684, UMMZ 117768).

Colima (MCZ 11417, 37156), Distrito Alvarez, $1 \mathrm{mi}$. SW Puebla Juarez (UMMZ 115581-82); Distrito Colima, Colima (CNHM 16161; UMMZ 80210).

Durango, Distrito Durango, ca. $10 \mathrm{mi}$. SW Durango (UMMZ 118944).

Guerrero, Distrito Bravos, $1 \mathrm{mi}$. W. Acahuizotla (TCWM 7427-32, 7501, 8579); vic. Chilpancingo (CNHM 38293-94; MVZ 45076-85; KUMNH 23781-83); $10.4 \mathrm{mi}$. S. Mexcala (UMMZ 118522); $4 \mathrm{mi}$. N. El Ocotito (TCWM 12650); Omilteme [3 miles northwest of Chilpancingo] (MCZ 42656).

Jalisco, Distrito Ahualulco, road to Cinco Minas, Hostotipaquillo (AMNH 19770); Distrito Chapala (?), Chapala (EHT 5192).

Michoacan, Distrito Tacambaro, about 10 miles south of Tacámbaro (UMMZ 99759); Distrito Uruapan, El Sabino (EHT 5190-91; UIMNH 17686).

Morelos, Distrito Tetecala, $20 \mathrm{mi}$. NNE Iguala (TCWM 12651).

Oaxaca, Distrito Huajuapan, $4.4 \mathrm{mi}$. NW Huajuapan (UMMZ 114404); Distrito Tehuantepec, 
Mixtaquilla Mountain (UMMZ 82570), Quiengola Mountain (AMNH 65119, 65891; UMMZ 82569); San Pedro Mountain (AMNH 65117, 66850), Santa Lucia, about 4,000 feet (AMNH 65118); Tenango (UIMNH 25104, 27575), Tres Cruces (USNM 110299-301); Distrito Teotitlan, Teotitlan (AMNH 65738) ; Distrito Zimatlan(?), San Andres Mixtepec (UIMNH 17685).

Puebla, Distrito Tehuacan, vic. Tehuacan (UMMZ 99891, 99893, 114601).

San Luis Potosi, Distrito Tamazunchale(?), 12.3 mi. N San Luis Potosi-Hidalgo boundary (UMMZ 117708).

Sinaloa, $13.8 \mathrm{mi}$. NNW Mazatlan (UMMZ 114600).

Sonora, Distrito Guaymas, $30 \mathrm{mi}$. N Guaymas (CalAc 6310).

Tamaulipas, Distrito Sur, about 5 miles N of Antiguo Morelos (UMMZ 101274), near Gómez Farías (111094-96), about 5 miles W of Pano Ayuctle (UMMZ 104043) .

United States, Arizona, Cochise County, Public Camp Ground at Chiricahua National Monument (INHS 8305; UIMNH 29182); Santa Cruz County, vicinity of Ruby (DZUA 500-01; W. H. Woodin 560), Santa Rita Mountains (CalAc 50185; ANSP 17895).

\section{Elaphe triaspis mutabilis $\times$ intermedia}

Guatemala, Departamento Chimaltenango, 10 kilometers northwest of Yepacapa (UMMZ 102560); Departamento Santa Rosa, Finca la Gloria (UMMZ 102561).

\section{Literature Cited}

Alvarez del Toro, Miguel, \& Hobart M. Smith 1956. Notulae Herpetologicae Chiapasiae I. Herpetologica, vol. 12, pt. 1, pp. 3-17.

Amaral, Afranio do

1929. Estudos Sobre Ophidios Neotropicos. XVIII. Lista Remissiva dos Ophidios da Regiaõ Neotropica. Mem. Inst. Butantan, vol. 4, pp. viii + 229-71.

ANDREWS, E. WyLlys

1937. Notes on snakes from the Yucatan Peninsula. Zool. Ser. Field Mus. Nat. Hist., vol. 20, no. 25, pp. 355-59.

Barbour, Thomas, \& Leon J. Cole

1906. Vertebrata from Yucatan. Reptilia, Amphibia, and Pisces. Bull. Mus. Comp. Zool., vol. 50, no. 5, pp. 146-59, pls. 2.

Blanchard, Frank N.

1925. A key to the snakes of the United States, Canada, and Lower California. Pap. Michigan Acad. Sci., Arts, Let., vol. 4, pt. 2, pp. xiii +65 , figs. 78 .

Bocourt, F.

1888. Mission Scientifique au Mexique et dans l'Amerique Centrale. $3 \mathrm{e}$ partie. Études sur les Reptiles et les Batraciens. Paris. folio, 11th livr., pp. 657-96, pls. 42-47.

BOETTGER, OSCAR

1883. Herpetologische Mittheilungen. I. Kurze Notizen über Reptilien und Amphibien in der Heidelberger Universitäts-Sammlung. Ber. des Offenbacher Vereins f. Naturkunde (22): pp. 147-52.

Boulenger, George A.

1894. Catalogue of the snakes in the British Museum (Natural History). Vol. II. London, pp. $11+382$, pls. 20 .

1896. Catalogue of the snakes in the British Museum (Natural History). Vol. III. London, pp. xiv +727 , pls. 25 .

CONANT, Roger

1938. The reptiles of Ohio. Amer. Midl. Nat., vol. 20 , no. 1 , pp. 1-200, 38 maps, 26 pls.

1940. A new subspecies of the fox snake, Elaphe vulpina Baird and Girard. Herpetologica, vol. 2, no. 1, pp. 1-14.

Cope, Edward D.

1866. Fourth contribution to the herpetology of Tropical America. II. A collection of reptiles from Belize from Dr. Parsons. Proc. Acad. Nat. Sci. Philadelphia, no. 2, pp. 123-32.

1879. Eleventh contribution to the herpetology of Tropical America. Proc. Amer. Philos. Soc., vol. 18, pp. 261-77.

1885. Twelfth contribution to the herpetology of Tropical America. Proc. Amer. Phil. Soc., vol. 22, pp. 167-194, 1 pl.

1887. Catalogue of batrachians and reptiles of Central America and Mexico. Bull. U. S. Natl. Mus., no. 32, pp. 1-98.

1892. A critical review of the characteristics and variations of the snakes of North America. Proc. U. S. Natl. Mus., vol. 14, no. 882 , pp. 589-694.

1900. The crocodilians, lizards and snakes of North America. Rept. U. S. Natl. Mus. for 1898: 153-1294, pls. 1-36.

Davis, William B.

1955. A new sheep toad (Genus Hypopachus) from Mexico. Herpetologica, vol 11, no. 1, pp. 71-72.

Dowling, Herndon G.

1951. A taxonomic study of the ratsnakes, genus Elaphe Fitzinger. I. The status of the name Scotophis laetus Baird and Girard (1853). Copeia, 1951, no. 1, pp. 39-44.

1952a. A taxonomic study of the American representatives of the genus Elaphe Fitzinger, with particular attention to the forms occurring in Mexico and Central America. Univ. Microfilms, no. 3743, 234 pp. 
1952b. A taxonomic study of the ratsnakes, genus Elaphe Fitzinger. IV. A check list of the American forms. Occ. Pap. Mus. Zool. Univ. Mich., no. 541, pp. 1-12.

1957. A taxonomic study of the ratsnakes, genus Elaphe Fitzinger. V. The Rosaliae Section. Occ. Pap. Mus. Zool. Univ. Mich., no. 583, pp. 1-22, 2 pls.

1958. A taxonomic study of the ratsnakes. VI. Validation of the genera Gonyosoma Wagler and Elaphe Fitzinger. Copeia, 1958 , no. 1 , pp. $29-40,3$ figs., 1 pl.

\section{Duellman, William E.}

1957. Notes on snakes from the Mexican state of Sinaloa. Herpetologica, vol. 13, pp. 237 40 .

1958. A preliminary analysis of the herpetofauna of Colima, Mexico. Occ. Pap. Mus. Zool., Univ. Mich., no. 589, pp. 1-22.

Gadow, Hans

1905. The distribution of Mexican amphibians and reptiles. Proc. Zool. Soc. London, vol. 2, pp. 191-244, pls., 6-7.

Gaige, Helen T.

1936. Some reptiles and amphibians from Yucatan and Campeche, Mexico. Pub. Carnegie Inst. Washington, no. 457, pp. 289-304.

Günther, Albert C. L. G.

1894. Reptilia and Batrachia. In Biologia Centrali-Americana. London, pp. $\mathrm{xx}+326$, pls. 1-76.

Hall, Charles W.

1951. Notes on a small herpetological collection from Guerrero. Univ. Kans. Sci. Bull., vol. 34 , no. 4, pp. 201-12, 1 pl.

Hartweg, Norman, \& James A. Oliver

1940. A contribution to the herpetology of the Isthmus of Tehuantepec. IV. An annotated list of the amphibians and reptiles collected on the Pacific Slope during the summer of 1936. Misc. Pub. Mus. Zool. Univ. Mich., no. 47, pp. 1-31.

KLAuber, L. M.

1943. Tail-length differences in snakes with notes on sexual dimorphism and the coefficient of divergence. Bull. Zool. Soc. San Diego, no. 18, pp. 5-60.

Martin, Paul S.

1955. Herpetological records from the Gomez Farias region of Southwestern Tamaulipas, Mexico. Copeia, 1955, no. 3, pp. 173 180.

1958. A biogeography of reptiles and amphibians in the Gomez Farias region, Tamaulipas, Mexico. Misc. Pub. Mus. Zool., Univ. Mich., no. 101, pp. 102, 7 pls., 7 figs.

\section{MERTENS, ROBERT}

1952a. Neues über die Reptilienfauna von El Salvador. Zool. Anzeiger, Bd. 148, Heft 3/4, pp. 87-93.

1952b. Die Amphibien und Reptilien von El Salvador, auf Grund der Reisen von R. Mertens und A. Zilch. Abh. Senckenbergischen Naturf. Ges., no. 487, pp. 1120,16 pls.

Mertens, Robert, \& Herndon G. Dowling

1952. The identity of the snake Pityophis intermedius Boettger, 1883. Senckenbergiana, Bd. 33, Num. 4/6, pp. 197-201, 1 fig.

Oliver, James A.

1937. Notes on a collection of amphibians and reptiles from the state of Colima, Mexico. Occ. Pap. Mus. Zool. Univ. Mich., no. 360 , pp. 1-28, 1 pl.

1948. The relationships and zoogeography of the genus Thalerophis Oliver. Bull. Amer. Mus. Nat. Hist., vol. 92, art. 4, pp. 157 280, 4 pls., 13 figs.

Perkins, C. B.

1940. A key to the snakes of the United States. Bull. Zool. Soc. San Diego, no. 16, pp. 1-63.

1949. A key to the snakes of the United States. 2nd ed. Bull. Zool. Soc. San Diego, no. 24, pp. 1-79.

Peters, James A.

1953. Snakes and lizards from Quintana Roo, Mexico. Lloydia, vol. 16, no. 3, pp. 227 232.

SCHMIDT, KARL P.

1941. The amphibians and reptiles of British Honduras. Zool. Ser. Field Mus. Nat. Hist., vol. 22, no. 8, pp. 475-510.

Schmidt, Karl P., \& E. Wyllys Andrews

1936. Notes on snakes from Yucatan. Zool. Ser. Field Mus. Nat. Hist., vol. 20, no. 18, pp. 167-87, figs. 20-23.

Shattuck, George C., et al

1933. The Peninsula of Yucatan: Medical, biological, meteorological and sociological studies. Pub. Carnegie Inst. Washington, no. 431 , pp. xvii +576 , pls. 1-67.

SMITH, Hobart M.

1938. Additions to the herpetofauna of Mexico. Copeia, 1938, no. 3 , pp. 149-50.

1941. Notes on Mexican snakes of the genus Elaphe. Copeia, 1941, no. 3, pp. 132-36, 2 figs.

1943. Summary of the collections of snakes and crocodilians made in Mexico under the Walter Rathbone Bacon travelling scholarship. Proc. U. S. Natl. Mus., vol. 93, no. 3169, pp. 393-504, pl. 32. 
SMith, Hobart M., \& Edward H. TAYLOR

1945. An annotated checklist and key to the snakes of Mexico. Bull. U. S. Natl. Mus., no. 187, pp. 1-239.

1950. Type localities of Mexican reptiles and amphibians. Univ. Kans. Sci. Bull., vol. 33 , pt. 2 , no. 8 , pp. 313-80.

Stejneger, Leonhard, \& Thomas Barbour

1917. A check list of North American amphibians and reptiles. Cambridge. Harvard Univ. Press, pp. iv + 125 .

\section{StONe, WitMer}

1911. On some collections of reptiles and batrachians from the Western United States. Proc. Acad. Nat. Sci. Phila., pp. 222-32.

\section{Stuart, Lawrence C.}

1948. The amphibians and reptiles of Alta Verapaz, Guatemala. Misc. Pub. Mus. Zool. Univ. Michigan, no. 69, pp. 1-109.

TAYLOR, EDWARD H.

1940. Some Mexican serpents. Univ. Kans. Sci. Bull., vol. 26, no. 14, pp. 445-87.

1949. A preliminary account of the herpetology of the state of San Luis Potosi, Mexico. Univ. Kans. Sci. Bull., vol. 33, pt. 1, no. 2, pp. 169-215.
1951. A brief review of the snakes of Costa Rica. Univ. Kans. Sci. Bull., vol. 34, pt. 1, no. 1, pp. 3-188, pls. 23.

TAYlor, EdWard H., \& IRVING W. KNOBloch

1940. Report on an herpetological collection from the Sierra Madre Mountains of Chihuahua. Proc. Biol. Soc. Wash., vol. 53, pp. 125-30.

VAN DENBURGH, JoHN

1922. The reptiles of western North America. Occ. Pap. Calif. Acad. Sci., vol. 10, no. 2, pp. 1-1028, pls. 1-128.

WERnER, Franz

1896. Beitrage zur Kenntniss der Reptilien und Batrachier von Centralamerika und Chile, sowie einiger seltenerer Schlangenarten. Verhandlungen der k. k. zool.-bot. Gesellschaft in Wein, Bd. 46, pp. 344-65, pl. 6.

1929. Übersicht der Gattungen und Arten der Schlangen aus der Familie Colubridae. III. Teil (Colubrinae). Zool. Jahrbücher, Bd. 57, pp. 1-196, figs. 1-48.

Woodbury, Angus M., \& Dixon M. Woodbury

1944. Notes on Mexican snakes from Oaxaca. Jour. Washington Acad. Sci., vol. 34, pp. 360-73. 


\section{EXPLANATION OF THE PLATE}

Plate I.

Elaphe triaspis Cope.

FIG. 1. Hemipenis of E. triaspis intermedia. The presence of two proximal hooks and the absence of proximal spinules and distal lobes is characteristic of this section of the genus. Drawn by William L. Brudon from the inverted hemipenis of UMMZ 80210 that was split and spread flat.

FIG. 2. Living individual of E. triaspis intermedia from the Chiricahua Mountains of Arizona. Photograph by Sam Dunton of a specimen collected by James A. Oliver. 


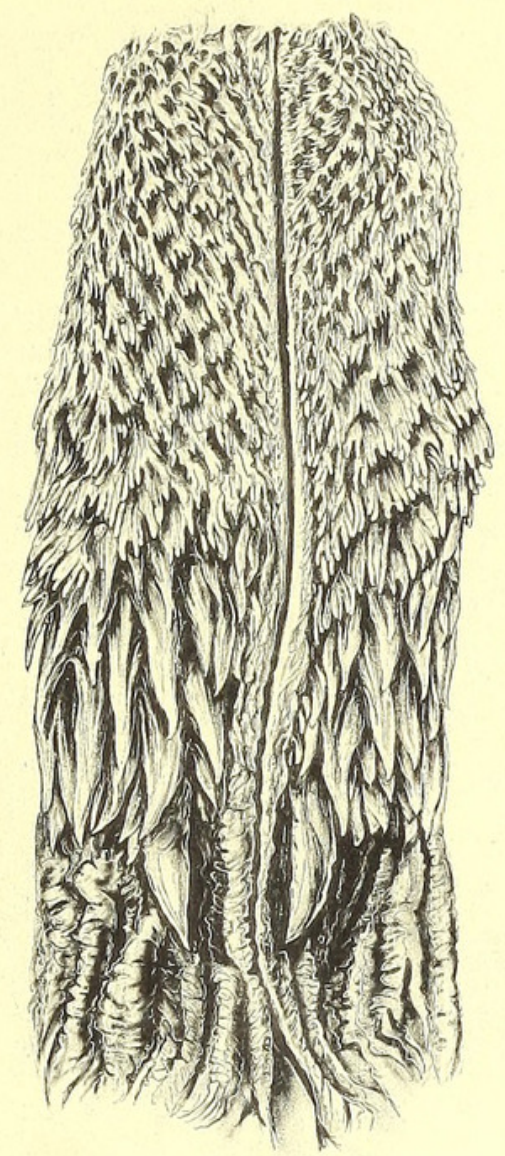

FIG. 1

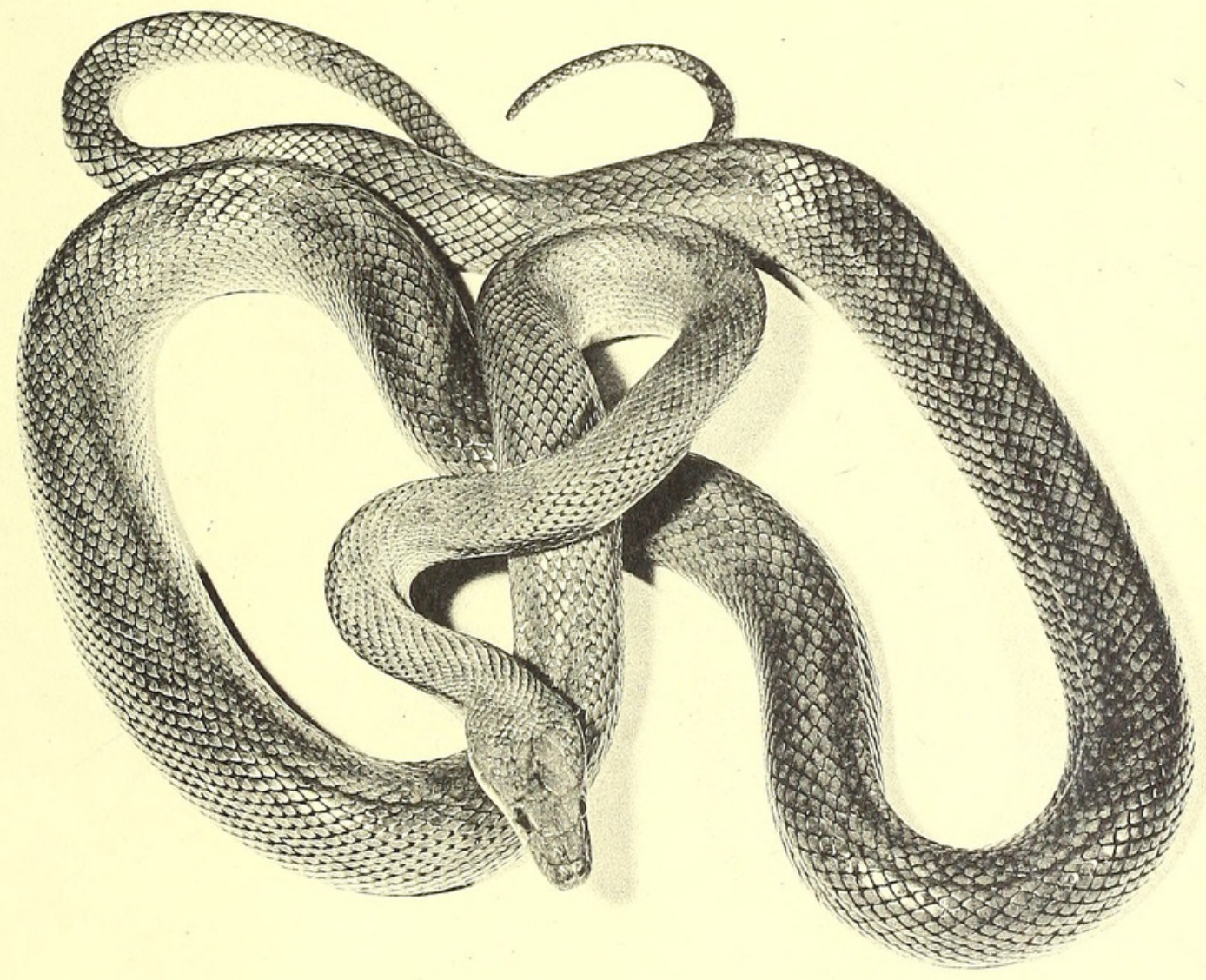

FIG. 2

A TAXONOMIC STUDY OF THE RATSNAKES, GENUS ELAPHE FITZINGER.

VII. THE TRIASPIS SECTION. 


\section{$2 \mathrm{BHL}$ Biodiversity Heritage Library}

Dowling, Herndon G. 1960. "A taxonomic study of the ratsnakes, genus Elaphe Fitzinger. VII. The triaspis section." Zoologica : scientific contributions of the New York Zoological Society 45(6), 53-80. https://doi.org/10.5962/p.203354.

View This Item Online: https://www.biodiversitylibrary.org/item/208290

DOI: https://doi.org/10.5962/p.203354

Permalink: https://www.biodiversitylibrary.org/partpdf/203354

\section{Holding Institution}

Smithsonian Libraries

\section{Sponsored by}

Biodiversity Heritage Library

\section{Copyright \& Reuse}

Copyright Status: In copyright. Digitized with the permission of the rights holder.

Rights Holder: Wildlife Conservation Society

This document was created from content at the Biodiversity Heritage Library, the world's largest open access digital library for biodiversity literature and archives. Visit BHL at https://www.biodiversitylibrary.org. 